\title{
Use of hydrophilic and hydrophobic polymers for the development of controlled release tizanidine matrix tablets
}

\author{
Tariq Ali ${ }^{1}$, Muhammad Harris Shoaib, ${ }^{1, *}$ Rabia Ismail Yousuf ${ }^{1}$, Sabahat Jabeen ${ }^{1}$, \\ Iyad Naeem Muhammad ${ }^{1}$, Asfia Tariq ${ }^{2}$
}

\author{
${ }^{1}$ Department of Pharmaceutics, Faculty of Pharmacy, University of Karachi, Karachi, Pakistan, ${ }^{2}$ Dow University of Health \\ Sciences, Karachi, Pakistan
}

\begin{abstract}
The aim of the present study was to develop tizanidine controlled release matrix. Formulations were designed using central composite method with the help of design expert version 7.0 software. Avicel pH 101 in the range of $14-50 \%$ was used as a filler, while HPMC K4M and K100M in the range of 25-55\%, Ethylcellulose $10 \mathrm{ST}$ and 10FP in the range of $15-45 \%$ and Kollidon SR in the range of 25-60\% were used as controlled release agents in designing different formulations. Various physical parameters including powder flow for blends and weight variation, thickness, hardness, friability, disintegration time and in-vitro release were tested for tablets. Assay of tablets were also performed as specified in USP 35 NF 32. Physical parameters of both powder blend and compressed tablets such as compressibility index, angle of repose, weight variation, thickness, hardness, friability, disintegration time and assay were evaluated and found to be satisfactory for formulations K4M2, K4M3, K4M9, K100M2, K100M3, K100M9, E10FP2, E10FP9, KSR2, KSR3 \& KSR9. In vitro dissolution study was conducted in $900 \mathrm{ml}$ of $0.1 \mathrm{~N} \mathrm{HCl}$, phosphate buffer $\mathrm{pH} 4.5$ and 6.8 medium using USP Apparatus II. In vitro release profiles indicated that formulations prepared with Ethocel 10 standard were unable to control the release of drug while formulations K4M2, K100M9, E10FP2 \& KSR2 having polymer content ranging from 40-55\% showed a controlled drug release pattern in the above mentioned medium. Zero-order drug release kinetics was observed for formulations K4M2, K100M9, E10FP2 \& KSR2. Similarity test $\left(f_{2}\right)$ results for K4M2, E10FP2 \& KSR2 were found to be comparable with reference formulation K100M9. Response Surface plots were also prepared for evaluating the effect of independent variable on the responses. Stability study was performed as per ICH guidelines and the calculated shelf life was 24-30 months for formulation K4M2, K100M9 and E10FP2.
\end{abstract}

Uniterms: Tizanidine/controlled release. Hydroxypropyl methylcellulose/controlled release agent. Ethylcellulose/controlled release agent. Kollidon SR/controlled release agent. Tablets/controlled release.

O objetivo do presente estudo foi desenvolver matriz de de tizanidina de liberação controlada. As formulações foram projetadas usando o método do componente, central com a ajuda de software Design expert $^{\circledR}$, versão 7.0. Utilizou-se Avicel pH 101, no intervalo de 14-50\%, como material de preenchimento, enquanto HPMC K4M e K100M, no intervalo de 25-55\%, Etilcelulose 10 ST e 10FP, no intervalo de $15-45 \%$ e Kollidon SR, na faixa de $25-60 \%$ foram utilizados como agentes de liberação controlada, no planejamento de formulações diferentes. Vários parâmetros físicos, incluindo o fluxo de pó para as misturas e variação de peso, espessura, dureza, friabilidade, tempo de desintegração e liberação in vitro, foram testados para comprimidos. Ensaios dos comprimidos foram, também, realizados, tal como especificado em USP 35 NF 32. Avaliaram-se os parâmetros físicos de ambos, mistura em pó e comprimidos, como índice de compressibilidade, ângulo de repouso, variação de peso, espessura, dureza, friabilidade, tempo de desintegração e de ensaio, considerando-os satisfatórios para as formulações K4M2, K4M3, K4M9, K100M2, K100M3, K100M9, E10FP2, E10FP9, KSR2, KSR3 e KSR9. O estudo de dissolução in vitro foi realizado em $900 \mathrm{~mL}$ de $\mathrm{HCl}$ 0,1 N, tampão de fosfato $\mathrm{pH}$ 4,5 e meio 6,8, usando

\footnotetext{
*Correspondence: Muhammad Harris Shoaib. Department of Pharmaceutics, University of Karachi, 75270 - Main University Road - Karachi - Sindh, Pakistan. E-mail: harrisshoaib2000@yahoo.com
} 
aparelho USP II. Os perfis de liberação in vitro indicaram que as formulações preparadas com Ethocel 10 padrão não foram capazes de controlar a liberação do fármaco, enquanto as formulações K4M2, K100M9, E10FP2e KSR2, com teor de polímero variando entre 40 e 55\% apresentaram padrão de liberação controlada de fármaco no meio anteriormente mencionado. Observou-se cinética de liberação de fármaco de ordem zero para as formulações K4M2, K100M9, E10FP2 e KSR2. Resultados do teste de similaridade $\left(f_{2}\right)$ para K4M2, E10FP2 e KSR2 foram comparáveis com a formulação de referência K100M9. Gráficos de superfície de resposta também avaliaram o efeito da variável independente sobre as respostas. Estudo de estabilidade foi realizado conforme as diretrizes do ICH e a vida de prateleira calculada foi de 24-30 meses para as formulações K4M2, K100M9 e E10FP2.

Unitermos: Tizanidina/liberação controlada.Hidroxipropilmetilcelulose/agente de liberação controlada. Etilcelulose/agente de liberação controlada. Kollidon SR./agente de liberação controlada. Comprimidos/ liberação controlada.

\section{INTRODUCTION}

Controlled release formulations of drugs may increase their therapeutic benefits, minimize side effects and enhance the patient compliance, therefore the overall disease management will be improved. Matrix based drug release systems offer many advantages such as the combination of matrix former and other materials can help in correlating the release characteristics to the requirements of drug and disease condition (Wilson, Crowley, 2011).

Tizanidine hydrochloride is an imidazoline derivative. It is a white to off white fine crystalline and odorless powder which is slightly soluble in water and methanol. Its solubility in water decreases with the increase in $\mathrm{pH}$ (Moffat, Osselton, Widdop, 2011). Acts on $\alpha_{2}$ receptors that are centrally located and produces a myotonolytic response on skeletal muscle (Wagstaff, Bryson, 1997) It acts mainly at spinal and supraspinal levels to inhibit excitatory inter neuron and is used for the symptomatic relief of spasticity associated with multiple sclerosis or with spinal cord injury or disease (Sweetman, 2009). It is also used in relieving pain with many disorders like myofascial (Meythaler et al., 2001), refractory and neuropathic pain, chronic tension type headache and chronic daily headache (Saper et al., 2002). After oral administration, tizanidine is widely absorbed from the gastrointestinal tract (53 to $66 \%$ ). Peak plasma concentration is achieved within 1 to $2 \mathrm{~h}$. It has a bioavailability of about $34 \%$ to $40 \%$ and has a half-life of $2.5 \mathrm{~h}$. Protein binding of tizanidine is $30 \%$ and it undergoes rapid and extensive first-pass metabolism in the liver (approximately $95 \%$ of a dose) (Shanker et al., 2009). The therapeutic dose of tizanidine is $2 \mathrm{mg}$ and $4 \mathrm{mg}$ twice a day. The maximum recommended dose is $36 \mathrm{mg} /$ day (Kulkarni, Babu, 2012). The short half-life, low bioavailability and extensive first-pass metabolism make tizanidine a good candidate for the development of controlled release formulations.
In the present study controlled release formulations of tizanidine hydrochloride were designed using different viscosity grades of hydroxopropyl methylcellulose, ethyl cellulose and Kollidon ${ }^{\circledR}$ SR. HPMC is an important hydrophilic polymer extensively used for controlled release dosage forms development (Siepmann, Streubel, Peppas, 2002). Its fast gel forming characteristics not only control the initial release but also exert sustained release effect through strong viscous gel formation (Reza, Quadir, Haider, 2003). Moreover, its non-toxic nature, easy compressibility made it ideal for controlled release formulations of many drugs (Shoaib et al., 2010). Ethyl cellulose is also a nontoxic, inert hydrophobic polymer widely used in sustained release formulations and to control the dissolution rate of drugs (Quadir et al., 2005). As a matrix forming excipient for controlled release formulations Kollidon ${ }^{\circledR}$ SR is also an extensively used polymer consisting of $80 \%$ water insoluble poly(vinyl acetate) with a molecular weight of about 450.000 and about $20 \%$ water soluble poly(vinyl pyrrolidone), named as Kollidon ${ }^{\circledR} 30$ (Strübing, Metz, Mäder, 2008). Many researchers (Draganoiu, Andheria, Sakr, 2001; Shao et al., 2001) used Kollidon ${ }^{\circledR}$ SR to delay the release of highly water soluble drugs such as propranolol $\mathrm{HCl}$, diphenhydramine $\mathrm{HCl}$ etc., with low friability and high crushing strengths at low compression pressure (Kolter, 2002).

Response surface methodology applied for illustration of effect of independent variables (such as polymers and fillers) on the dependent variables or responses (such as disintegration time and drug release). Response surface methodology (RSM) is a statistical tool for optimization of multifactor experiments (Hamsaveni, Prapulla, Divakar, 2001; Chiang, Chang, Shieh, 2003; Zhang et al., 2007). It is used to illustrate the correlation between independent variables and responses (Vicente et al., 1998). RSM require less effort with minimum number of trials as compare to other approaches (Liyana- 
Pathirana, Shahidi, 2005; Xiong et al., 2009). Central composite rotatable design (CCRD), is one of the design approaches in RSM, was developed by Box and Wilson (Box, Wilson, 1951) and later improvement has been made in this design by Box and Hunter (Box, Hunter, 1957). CCRD is an effective optimization technique which enables to recognize optimum responses around center points through its rotatable characteristics (Zhang et al., $2010 \mathrm{a}$ ).

The aim of present work is to develop controlled release tizanidine matrix tablets using different polymers i.e., HPMC, Ethocel and Kollidon ${ }^{\circledR}$ SR, by direct compression method. Formulation of controlled release tizanidine tablets with these polymers using software Design expert ${ }^{\circledR}$ and application of response surface models, has not been reported earlier. Study showed importance and give a detailed analysis of work which proved formulation of tizanidine with hydrophilic and hydrophobic polymers.

\section{MATERIAL AND METHODS}

\section{Material}

The following materials were used: tizanidine hydrochloride (Novartis Pharma, Karachi), HPMC K4M \& K100M, Ethocel 10 Standard Premium and Ethocel 10 FP (Colorcon, England), Kollidon SR (BASF, Germany) Avicel PH 101 (FMC Corporation, USA) and magnesium stearate (Dow Chemical, USA).

\section{Methods}

\section{Calculation of dose for controlled release tizanidine tablets}

The total dose for tizanidine controlled release tablet can be calculated by using the following equation (Shoaib et al., 2010).

$$
\mathrm{D}_{\mathrm{t}}=\mathrm{D}_{\mathrm{n}}\left(1+0.693 \times \mathrm{T}_{\mathrm{d}} / \mathrm{t}_{1 / 2}\right)
$$

where $D_{t}$ is the prolonged action dose, $D_{n}$ is the normal dose and $T_{d}$ is a required maintenance time.

For tizanidine hydrochloride, immediate release dose $\left(D_{n}\right)$ is $4 \mathrm{mg}$ and half-life is 2.5 hours. Therefore, for a controlled release during $24 \mathrm{~h}\left(\mathrm{~T}_{\mathrm{d}}\right), 30 \mathrm{mg}$ of tizanidine (equivalent to $34 \mathrm{mg}$ of tizanidine hydrochloride) per tablet was taken.

\section{Preparation of tablets}

Formulations were designed by using a software
Design expert ${ }^{\circledR}$. Different formulations of HPMC viscosity grades of K4M \& K100M, Ethocel 10 ST (standard grade) \& $10 \mathrm{FP}$ (fine particle grade) and Kollidon SR were prepared by direct compression method. Each tablet containing $34 \mathrm{mg}$ of tizanidine hydrochloride (equivalent to $30 \mathrm{mg}$ of tizanidine) and $2 \mathrm{mg}$ of magnesium stearate, while polymers HPMC $\mathrm{K} 4 \mathrm{M} \& \mathrm{~K} 100 \mathrm{M}$ ranging from 25 to $55 \%$, Ethocel 10ST \& $10 \mathrm{FP}(15 \%$ to $45 \%)$ and Kollidon SR (25 to $60 \%)$ were used as independent variable (X1) and Avicel PH 101(14 to $50 \%$ in HPMC formulations, 26 to $48 \%$ in Ethocel formulations and $8-51 \%$ in Kollidon SR formulations) was used as second independent variable (X2). Formulation excipients and active ingredient were passed through 40-mesh size sieve and accurately weighed. Excipients and active ingredient of each formulation were blended by tumbling method in a polybag for about 8-10 min and then compressed on manually operated single punch tablet press (Korsch Erweka, Frankfurt, Germany). Convex round shaped punch was used and tablets were pressed in a range of 96 to $126 \mathrm{mg}$.

\section{Experimental design}

To find out the optimum level of variable, a two factor with five levels CCD was developed. It consists of factorial points at two levels, axial points at two levels and center point. Hence, independent variables (X1:Polymer and X2: Avicel PH 101) at five levels were considered. The levels were $-\alpha,-1,0,1$ and $+\alpha$. The alpha value (1.414) was taken to execute design rotatibility. Disintegration time and drug release both at 2 and $8 \mathrm{~h}$ were selected as responses. The coded and actual values of variables are given in Table I. By using Design Expert software (Version 7, Stat-Ease Inc., Minneapolis, MN), CCD generated a total of nine (9) experiments with four factorial, four axial and one center point. Hao et al also used central composite response surface design with five replicated center points (Hao et al., 2012).

\section{Micromeritic Study}

Micromeritic properties of powder blends such as tapped density, bulk density, Hausner's ratio, compressibility index and angle of repose were evaluated using the procedure specified in US pharmacopeia (USP35-NF30, 2012).

Hausner's ratio, compressibility index and angle of repose were calculated by the following equations.

$$
\text { Hausner's ratio }=\left(\rho_{\text {tapped }} / \rho_{\text {bulk }}\right)
$$

Compressibility Index $=\left[100 \times\left(\rho_{\text {tapped }}-\rho_{\text {bulk }}\right) / \rho_{\text {tapped }}\right]$ Eq (3) 
TABLE I - A two factor central composite rotatable design of experiments for tizanidine formulations

\begin{tabular}{|c|c|c|c|c|c|c|c|c|}
\hline \multirow{3}{*}{$\begin{array}{c}\begin{array}{c}\text { Formulation } \\
\text { Code }\end{array} \\
H P M C K 4 M\end{array}$} & \multicolumn{2}{|c|}{ Coded factor level } & \multirow{2}{*}{\multicolumn{2}{|c|}{$\begin{array}{c}\text { Factors Amount } \\
(\%)\end{array}$}} & \multirow{2}{*}{\multicolumn{2}{|c|}{$\begin{array}{c}\begin{array}{c}\text { Factors Amount } \\
(\mathrm{mg})\end{array} \\
\end{array}$}} & \multirow{3}{*}{$\begin{array}{l}\text { Total Wt. of } \\
\text { Tablet (mg) }\end{array}$} & \multirow{3}{*}{$\begin{array}{c}\text { Total wt. } \\
\text { adjusted (mg) }\end{array}$} \\
\hline & \multirow{2}{*}{$\begin{array}{c}\mathbf{X} \mathbf{1} \\
H P M C K 4 M\end{array}$} & \multirow{2}{*}{$\frac{\mathbf{X ~ 2}}{\text { Avicel PH } 101}$} & & & & & & \\
\hline & & & HPMC K $4 M$ & Avicel PH 101 & HPMC K $4 M$ & Avicel PH 101 & & \\
\hline K4M 1 & -1 & -1 & 30.00 & 20.00 & 30.84 & 20.56 & 87.40 & 88 \\
\hline K4M 2 & 1 & -1 & 50.00 & 20.00 & 51.40 & 20.56 & 107.96 & 108 \\
\hline K4M 3 & -1 & 1 & 30.00 & 45.00 & 30.84 & 46.26 & 113.10 & 113 \\
\hline K4M 4 & 1 & 1 & 50.00 & 45.00 & 51.40 & 46.26 & 133.66 & 134 \\
\hline K4M 5 & -1.414 & 0 & 25.86 & 32.50 & 26.58 & 33.41 & 95.99 & 96 \\
\hline K4M 6 & 1.414 & 0 & 54.14 & 32.50 & 55.66 & 33.41 & 125.07 & 125 \\
\hline K4M 7 & 0 & -1.414 & 40.00 & 14.82 & 41.12 & 15.23 & 92.35 & 93 \\
\hline K4M 8 & 0 & 1.414 & 40.00 & 50.18 & 41.12 & 51.58 & 128.70 & 128 \\
\hline K4M 9 & 0 & 0 & 40.00 & 32.50 & 41.12 & 33.41 & 110.53 & 110 \\
\hline HРMC К100M & HРMC K100M & Avicel PH 101 & HРMC K100M & Avicel PH 101 & HРMC К100M & Avicel PH 101 & & \\
\hline K100M 1 & -1 & -1 & 30.00 & 20.00 & 30.84 & 20.56 & 87.40 & 88 \\
\hline $\mathrm{K} 100 \mathrm{M} 2$ & 1 & -1 & 50.00 & 20.00 & 51.40 & 20.56 & 107.96 & 108 \\
\hline K100M 3 & -1 & 1 & 30.00 & 45.00 & 30.84 & 46.26 & 113.10 & 113 \\
\hline $\mathrm{K} 100 \mathrm{M} 4$ & 1 & 1 & 50.00 & 45.00 & 51.40 & 46.26 & 133.66 & 134 \\
\hline K100M 5 & -1.414 & 0 & 25.86 & 32.50 & 26.58 & 33.41 & 95.99 & 96 \\
\hline K100M 6 & 1.414 & 0 & 54.14 & 32.50 & 55.66 & 33.41 & 125.07 & 125 \\
\hline K100M 7 & 0 & -1.414 & 40.00 & 14.82 & 41.12 & 15.23 & 92.35 & 93 \\
\hline K100M 8 & 0 & 1.414 & 40.00 & 50.18 & 41.12 & 51.58 & 128.70 & 128 \\
\hline K100M 9 & 0 & 0 & 40.00 & 32.50 & 41.12 & 33.41 & 110.53 & 110 \\
\hline Ethocel 10 Standard & Ethocel $10 S T$ & Avicel PH 101 & Ethocel 10 ST & Avicel PH 101 & Ethocel $10 S T$ & Avicel PH 101 & & \\
\hline E10ST 1 & -1 & -1 & 20.00 & 30.00 & 22.00 & 33.00 & 91.00 & 91 \\
\hline E10ST 2 & 1 & -1 & 40.00 & 30.00 & 44.00 & 33.00 & 113.00 & 113 \\
\hline E10ST 3 & -1 & 1 & 20.00 & 45.00 & 22.00 & 49.50 & 107.50 & 108 \\
\hline E10ST 4 & 1 & 1 & 40.00 & 45.00 & 44.00 & 49.50 & 129.50 & 130 \\
\hline E10ST 5 & -1.414 & 0 & 15.86 & 37.50 & 17.45 & 41.25 & 94.70 & 95 \\
\hline E10ST 6 & 1.414 & 0 & 44.14 & 37.50 & 48.56 & 41.25 & 125.81 & 126 \\
\hline E10ST 7 & 0 & -1.414 & 30.00 & 26.89 & 33.00 & 29.58 & 98.58 & 99 \\
\hline E10ST 8 & 0 & 1.414 & 30.00 & 48.11 & 33.00 & 52.92 & 121.92 & 122 \\
\hline E10ST 9 & 0 & 0 & 30.00 & 37.50 & 33.00 & 41.25 & 110.25 & 110 \\
\hline Ethocel $10 \mathrm{FP}$ & Ethocel $10 \mathrm{FP}$ & Avicel PH 101 & Ethocel $10 \mathrm{FP}$ & Avicel PH 101 & Ethocel $10 \mathrm{FP}$ & Avicel PH 101 & & \\
\hline E10FP 1 & -1 & -1 & 20.00 & 30.00 & 22.00 & 33.00 & 91.00 & 91 \\
\hline E10FP 2 & 1 & -1 & 40.00 & 30.00 & 44.00 & 33.00 & 113.00 & 113 \\
\hline E10FP 3 & -1 & 1 & 20.00 & 45.00 & 22.00 & 49.50 & 107.50 & 108 \\
\hline E10FP 4 & 1 & 1 & 40.00 & 45.00 & 44.00 & 49.50 & 129.50 & 130 \\
\hline E10FP 5 & -1.414 & 0 & 15.86 & 37.50 & 17.45 & 41.25 & 94.70 & 95 \\
\hline E10FP 6 & 1.414 & 0 & 44.14 & 37.50 & 48.56 & 41.25 & 125.81 & 126 \\
\hline E10FP 7 & 0 & -1.414 & 30.00 & 26.89 & 33.00 & 29.58 & 98.58 & 99 \\
\hline E10FP 8 & 0 & 1.414 & 30.00 & 48.11 & 33.00 & 52.92 & 121.92 & 122 \\
\hline E10FP 9 & 0 & 0 & 30.00 & 37.50 & 33.00 & 41.25 & 110.25 & 110 \\
\hline Kollidon $S R$ & $K S R$ & Avicel PH 101 & $K S R$ & Avicel PH 101 & $K S R$ & Avicel PH 101 & & \\
\hline KSR 1 & -1 & -1 & 30.00 & 15.00 & 33.00 & 16.50 & 85.50 & 86 \\
\hline KSR 2 & 1 & -1 & 55.00 & 15.00 & 60.50 & 16.50 & 113.00 & 113 \\
\hline KSR 3 & -1 & 1 & 30.00 & 45.00 & 33.00 & 49.50 & 118.50 & 118 \\
\hline KSR 4 & 1 & 1 & 55.00 & 45.00 & 60.50 & 49.50 & 146.00 & 146 \\
\hline KSR 5 & -1.414 & 0 & 24.82 & 30.00 & 27.30 & 33.00 & 96.30 & 96 \\
\hline KSR 6 & 1.414 & 0 & 60.18 & 30.00 & 66.20 & 33.00 & 135.20 & 135 \\
\hline KSR 7 & 0 & -1.414 & 42.50 & 8.79 & 46.75 & 9.67 & 92.42 & 92 \\
\hline KSR 8 & 0 & 1.414 & 42.50 & 51.21 & 46.75 & 56.33 & 139.08 & 139 \\
\hline KSR 9 & 0 & 0 & 42.50 & 30.00 & 46.75 & 33.00 & 115.75 & 116 \\
\hline
\end{tabular}




$$
\tan (\alpha)=\text { height } / 0.5 \text { base }
$$

where $\rho_{\text {tapped }}$ and $\rho_{\text {bulk }}$ were the tapped and bulk densities of blends, respectively and $\alpha$ was the angle of repose.

\section{Evaluation of tizanidine tablets}

Tizanidine tablets were evaluated using several physical parameters including weight variation, hardness, thickness, friability and disintegration. Weight variation was performed by using digital balance (Sartorius CP 224S, Germany) for all compressed formulations. Tablet hardness was determined using Fujiwara Seisakusho tablet hardness tester, Ogawa Seiko Co Ltd, Tokyo, Japan. Tablet disintegration test were performed using USP basket rack assembly (Erweka disintegration tester, ZT2, Heusenstamm, Germany). Tablet friability was carried out using Roche type friabilator (H Jurgens friabilator GmbH \& Co. D-2800 Breman, Germany) (USP 35-NF 30, 2012).

\section{Swelling studies}

Swelling studies of tablets were performed by gently placing a tablet (using a wire) in a beaker containing about $250 \mathrm{~mL}$ of distilled water at room temperature. The weights of swollen tablets (after absorbing excess water through a filter paper) were recorded at 1, 2, 3, 4, 6 and $8 \mathrm{~h}$. Water uptake (\%) was expressed as a percentage of initial tablet weight (Cao et al., 2005).

$$
\% \mathrm{~S}=\frac{\mathrm{W}_{\mathrm{t}}-\mathrm{W}_{\mathrm{o}}}{\mathrm{W}_{0}} \times 100
$$

where $\mathrm{S}$ is the swelling of tablet, $\mathrm{Wt}$ is the weight of swollen tablet and Wo is the initial weight of tablet.

\section{Dissolution studies}

Dissolution studies were performed by placing six tablets of each formulation in $900 \mathrm{~mL}$ of dissolution medium at $37 \pm 0.5^{\circ} \mathrm{C}$ using a USP apparatus II dissolution tester (DT 600, Erweka, Germany). Paddles were rotated at $100 \mathrm{rpm}$ and the medium used was $0.1 \mathrm{~N} \mathrm{HCl}$, Phosphate buffer at $\mathrm{pH} 4.5 \&$ 6.8. Samples were analyzed using UVVIS spectrophotometer (UV-1800, Shimadzu, Kyoto, Japan) at $320 \mathrm{~nm}$ by withdrawing $5 \mathrm{~mL}$ of aliquots at regular time interval of 30min, 1, 2, 3, 4, 5, 6, 8, 10, 12, 16,20 and $24 \mathrm{~h}$ and filtered using a $0.45 \mu \mathrm{m}$ filter. These aliquots were replaced by the same medium previously maintained at $37 \pm 0.5^{\circ} \mathrm{C}$.

\section{Quantification of tizanidine in the formulation}

Drug quantification was performed using high performance liquid chromatographic method. The mobile phase was composed of acetonitrile and buffer solution of sodium 1-petanesulfonate in a ratio of 4:1 (buffer solution was prepared by adding $3.5 \mathrm{~g}$ of sodium 1-pentane sulfonate in 1 liter of water and $\mathrm{pH}$ was adjusted with phosphoric acid solution or $1 \mathrm{~N}$ sodium hydroxide at $\mathrm{pH}$ $3.0 \pm 0.05)$. The HPLC system consists of a pump LC- 10 AT VP, Communication Bus Module CBM 102, and a UV detector SPD 10-A VP (Shimadzu Corp, Tokyo, Japan). The column used was Intersil ODS-3, 4.6 x 250mm which was maintained at $50{ }^{\circ} \mathrm{C}$ in a column oven (CTO-10A, Shimadzu Corp., Kyoto, Japan) with a flow rate of $1 \mathrm{~mL} / \mathrm{min}$. Injection volume was $10 \mu \mathrm{L}$ and detection wave length was $230 \mathrm{~nm}$. Software used was class GC 10 ver. 2.0 (1993-2000), (Shimadzu Corp., Kyoto, Japan) was used for data processing (USP 35-NF 30, 2012).

\section{Stability studies}

The optimized formulations were then subjected to accelerated stability study as per ICH guidelines i.e. by placing tablets in a Stability chamber ((Binder GMBH Bergster, Tullingen, Germany) at $40 \pm 2{ }^{\circ} \mathrm{C}$ and $75 \pm 5 \%$ $\mathrm{RH}$ (ICH, 2003). The samples were removed and tested at $0,1,3$ and 6 months and different physico-chemical parameters like hardness, friability, disintegration, dissolution and quantification were assessed. The shelf life was calculated using R-Gui version 2.15.2 (stab) package (The R Foundation for Statistical Computing).

\section{Data Analysis}

- Model-dependent methods

In order to propose mechanism of drug release from these formulations, in vitro dissolution profiles data were fitted into different kinetic models. These models were zero order (cumulative amount of drug released $v s$ time), first-order (log cumulative percentage of drug remaining $v s$ time), Higuchi's (cumulative percentage of drug released $v s$ square root of time), Hixson-Crowell (cube root percent drug remaining $v s$ time) and Korsmeyer's (log cumulative percentage of drug released vs log time).

- Zero order equation:

$$
\mathrm{Q}_{\mathrm{t}}=\mathrm{K}_{\mathrm{o}} \mathrm{t}
$$

where $\mathrm{K}_{\mathrm{o}}$ is the zero-order rate constant expressed in units of concentration/time, $\mathrm{t}$ is the time in hours, and $\mathrm{Q}_{\mathrm{t}}$ is the amount of drug release in time $t$.

- First-order equation:

$$
\log Q_{t}=\log Q_{o}-k_{t} / 2.303
$$


where $Q_{t}$ is the amount released at time $t, Q_{o}$ is the initial amount of drug in solution and $k$ is the first order rate constant and $t$ is the time.

- Higuchi's equation:

$$
\mathrm{Q}=\mathrm{kt}^{1 / 2}
$$

where $\mathrm{k}$ is the release rate constant and $\mathrm{t}$ is the time in hours. Hence, the drug release rate is proportional to the reciprocal of the square root of time (David, 2002).

- Hixson-Crowell Cube Root equation

$$
\mathrm{Q}_{\mathrm{o}}{ }^{1 / 3}-\mathrm{Q}_{\mathrm{t}}^{1 / 3}=\mathrm{K}_{\mathrm{HC}} \times \mathrm{t}
$$

where $K_{\mathrm{HC}}$ is the Hixson-Crowell rate constant, $\mathrm{Q}_{\mathrm{o}}$ is the intial amount of drug and $\mathrm{Q}_{t}$ is the amount of drug release at time $\mathrm{t}$ (Higuchi, 1963).

For zero order, Higuchi, and Hixson-Crowell model, the rate constant were also calculated that is simply equal to the slope of the straight line:

$$
\mathrm{K}_{\mathrm{o}}=\text { Slope }
$$

Below is showed the equation used for first-order rate constant

$$
\mathrm{K}=- \text { Slope } \times 2.303
$$

Korsmeyer's equation (Power law),

$$
\mathrm{M}_{\mathrm{t}} / \mathrm{M}_{\infty}=\mathrm{Kt}^{\mathrm{n}}
$$

where $M_{t}$ is the amount of drug released at time $t, M_{\infty}$ is the amount of drug released after infinite time (total drug in a dosage form), $\mathrm{K}$ is the Korsmeyer's dissolution rate constant and $\mathrm{n}$ is the release exponent which was calculated through the slope of the straight line which characterizes the mechanism of release (Hixson, Crowell, 1931).

For matrix devices that are cylindrical-shaped, if the exponent $n$ value is 0.45 it is indicative of Fickian release (case I), for non-Fickian release (anomalous) it should be $>0.45$ but $<0.89$, value of 0.89 is indicative of case II (zero order) release, and $>0.89$ is super case II type of release (Korsmeyer et al., 1983).

\section{Model Independent Method}

- Similarity Factor $\left(f_{2}\right)$

The similarity factor $\left(f_{2}\right)$ is a logarithmic reciprocal square root transformation of the sum of squared error and is a measurement of the similarity in the percent dissolution between the two curves:

$f_{2}=50 \times \log \left\{\left[1+\left(\frac{1}{N}\right) \sum\left(\mathrm{R}_{\mathrm{i}}-\mathrm{T}_{\mathrm{i}}\right)^{2}\right]^{-0.5}\right\} \times 100 \quad \mathrm{Eq}(13)$

where $R_{i}$ is the percent dissolved of referenced drug, $T_{i}$ is the percent dissolved of test drug at each time point and $\mathrm{N}$ is the number of samples. Its value will be 100 where test and reference drug profiles are identical. Dissimilarity in profiles increases with the decrease in $f_{2}$ (Costa, Sousa Lobo, 2001).

\section{RESULTS AND DISCUSSION}

\section{Formulation of tizanidine matrix tablets}

Tizanidine controlled release formulations were designed using software Design Expert version 7.0. The coded and actual quantities of individual content of tablet for different polymers i.e HPMC (K4M \& K100M) Ethocel (10 ST \& 10 FP) and Kollidon SR are shown in Table I. HPMC K4M and K100M formulations were assigned formulation code $\mathrm{K} 4 \mathrm{M}$ and $\mathrm{K} 100 \mathrm{M}$ as prefix followed by numeric number as suffix. Similarly, formulations containing Ethocel 10 Standard grade, Ethocel 10 fine particle grade and Kollidon SR were assigned formulation codes E10ST, E10FP and KSR, respectively and followed by a numeric number as suffix.

\section{Evaluation of powder blends and tablets}

Micromeritic evaluation of powder blends, Hausner's ratio, compressibility index and angle of repose were calculated for the formulations and showed in Table II. The powder blends which comply with USP standard and categorized as Fair to Excellent, were chosen for compression and further studies. The formulations which complied with USP standards in terms of flow properties were K4M2, K4M3, K4M5, K4M9, K100M2, K100M 3, K100M 5, K100M9, E10ST 2, E10ST 6, E10ST 9, E10FP 2, E10FP 3, E10FP 9, KSR 2, KSR 3, KSR 5 and KSR 9. These formulations were evaluated for physical parameters such as thickness, hardness, weight variation, friability, disintegration time and assay (Table III). The mean thickness and hardness of tablets were in the range of $3.67 \pm 0.14$ to $4.39 \pm 0.18 \mathrm{~mm}$ and $3.40 \pm 0.78$ to $12.92 \pm 1.80 \mathrm{~kg}$, respectively. Powder flowability and level of powder in dye often regulate variation in tablet thickness (Davies, 1995). The hardness is an attribute 
due to binding characteristic of the filler and the force of compression with which the ingredients have been compressed (Siddiqui, Nazzal, 2007). Weight variation was in the range of $95.74 \pm 6.32$ to $125.35 \pm 4.53 \mathrm{mg}$. Friability of compressed formulations was $<1 \%$ except for formulations K4M5 and KSR5. Disintegration time of less than 4 hours was observed for K4M5, K100M5, E10ST 2, 6 \& 9, E10FP3 and KSR 5 formulations. Early disintegration observed in formulation where the concentration of polymers was low, it seemed that low

TABLE II - Micromeritic Properties of different formulation blends

\begin{tabular}{|c|c|c|c|c|c|c|c|c|c|}
\hline $\begin{array}{l}\text { Formulation } \\
\text { code }\end{array}$ & Mass & $\begin{array}{c}\text { Bulk } \\
\text { Volume }\end{array}$ & $\begin{array}{l}\text { Tapped } \\
\text { volume }\end{array}$ & $\begin{array}{c}\text { Bulk } \\
\text { density }\end{array}$ & $\begin{array}{l}\text { Tapped } \\
\text { density }\end{array}$ & $\begin{array}{c}\text { Haunser } \\
\text { Ratio }\end{array}$ & $\begin{array}{c}\text { Compressibility } \\
\text { Index }\end{array}$ & $\begin{array}{l}\text { Angle of } \\
\text { repose }\end{array}$ & $\begin{array}{c}\text { Flow } \\
\text { properties } \\
\text { according to }\end{array}$ \\
\hline & (g) & $(\mathrm{mL})$ & $(\mathrm{mL})$ & (g/mL) & $(\mathrm{g} / \mathrm{mL})$ & & $\%$ & $\theta$ & USP 35 \\
\hline K4M 1 & 10.00 & 17.00 & 12.00 & 0.59 & 0.83 & 1.42 & 29.41 & 53.28 & Poor \\
\hline K4M 2 & 10.00 & 17.00 & 16.00 & 0.59 & 0.63 & 1.06 & 5.88 & 29.56 & Excellent \\
\hline K4M 3 & 10.00 & 19.00 & 16.00 & 0.53 & 0.63 & 1.19 & 15.79 & 36.32 & Fair \\
\hline $\mathrm{K} 4 \mathrm{M} 4$ & 10.00 & 20.00 & 14.00 & 0.50 & 0.71 & 1.43 & 30.00 & 49.83 & Poor \\
\hline K4M 5 & 10.00 & 20.00 & 16.00 & 0.50 & 0.63 & 1.25 & 20.00 & 38.39 & Fair \\
\hline K4M 6 & 10.00 & 20.00 & 14.00 & 0.50 & 0.71 & 1.43 & 30.00 & 53.99 & Poor \\
\hline K4M 7 & 10.00 & 17.00 & 12.00 & 0.59 & 0.83 & 1.42 & 29.41 & 54.21 & Poor \\
\hline K4M 8 & 10.00 & 18.00 & 12.00 & 0.56 & 0.83 & 1.50 & 33.33 & 58.18 & V Poor \\
\hline K4M 9 & 10.00 & 17.00 & 15.00 & 0.59 & 0.67 & 1.13 & 11.76 & 33.20 & Good \\
\hline K100M 1 & 10.00 & 17.00 & 11.00 & 0.59 & 0.91 & 1.55 & 35.29 & 60.79 & V Poor \\
\hline $\mathrm{K} 100 \mathrm{M} 2$ & 10.00 & 18.00 & 16.00 & 0.56 & 0.63 & 1.13 & 11.11 & 32.11 & Good \\
\hline K100M 3 & 10.00 & 20.00 & 17.00 & 0.50 & 0.59 & 1.18 & 15.00 & 33.28 & Good \\
\hline $\mathrm{K} 100 \mathrm{M} 4$ & 10.00 & 19.00 & 11.00 & 0.53 & 0.91 & 1.73 & 42.11 & 70.45 & V V Poor \\
\hline K100M 5 & 10.00 & 17.00 & 13.00 & 0.59 & 0.77 & 1.31 & 23.53 & 38.12 & Fair \\
\hline K100M 6 & 10.00 & 20.00 & 15.00 & 0.50 & 0.67 & 1.33 & 25.00 & 42.66 & Passable \\
\hline K100M 7 & 10.00 & 17.00 & 12.00 & 0.59 & 0.83 & 1.42 & 29.41 & 46.32 & Poor \\
\hline K100M 8 & 10.00 & 17.00 & 11.00 & 0.59 & 0.91 & 1.55 & 35.29 & 60.28 & V Poor \\
\hline K100M 9 & 10.00 & 18.00 & 17.00 & 0.56 & 0.59 & 1.06 & 5.56 & 27.19 & Excellent \\
\hline E10ST 1 & 10.00 & 24.00 & 16.00 & 0.42 & 0.63 & 1.50 & 33.33 & 61.24 & V Poor \\
\hline E10ST 2 & 10.00 & 23.00 & 19.00 & 0.43 & 0.53 & 1.21 & 17.39 & 38.13 & Fair \\
\hline E10ST 3 & 10.00 & 23.00 & 17.00 & 0.43 & 0.59 & 1.35 & 26.09 & 51.22 & Poor \\
\hline E10ST 4 & 10.00 & 22.00 & 15.00 & 0.45 & 0.67 & 1.47 & 31.82 & 58.54 & V Poor \\
\hline E10ST 5 & 10.00 & 23.00 & 15.00 & 0.43 & 0.67 & 1.53 & 34.78 & 64.87 & V Poor \\
\hline E10ST 6 & 10.00 & 24.00 & 21.00 & 0.42 & 0.48 & 1.14 & 12.50 & 34.25 & Good \\
\hline E10ST 7 & 10.00 & 24.00 & 18.00 & 0.42 & 0.56 & 1.33 & 25.00 & 43.30 & Passable \\
\hline E10ST 8 & 10.00 & 21.00 & 15.00 & 0.48 & 0.67 & 1.40 & 28.57 & 48.74 & Poor \\
\hline E10ST 9 & 10.00 & 22.00 & 18.00 & 0.45 & 0.56 & 1.22 & 18.18 & 37.34 & Fair \\
\hline E10FP 1 & 10.00 & 27.00 & 21.00 & 0.37 & 0.48 & 1.29 & 22.22 & 43.23 & Passable \\
\hline E10FP 2 & 10.00 & 28.00 & 24.00 & 0.36 & 0.42 & 1.17 & 14.29 & 32.12 & Good \\
\hline E10FP 3 & 10.00 & 29.00 & 24.00 & 0.34 & 0.42 & 1.21 & 17.24 & 37.75 & Fair \\
\hline E10FP 4 & 10.00 & 31.00 & 24.00 & 0.32 & 0.42 & 1.29 & 22.58 & 44.09 & Passable \\
\hline E10FP 5 & 10.00 & 31.00 & 22.00 & 0.32 & 0.45 & 1.41 & 29.03 & 53.37 & Poor \\
\hline E10FP 6 & 10.00 & 30.00 & 20.00 & 0.33 & 0.50 & 1.50 & 33.33 & 58.16 & V Poor \\
\hline E10FP 7 & 10.00 & 28.00 & 18.00 & 0.36 & 0.56 & 1.56 & 35.71 & 62.97 & V Poor \\
\hline E10FP 8 & 10.00 & 29.00 & 22.00 & 0.34 & 0.45 & 1.32 & 24.14 & 44.23 & Passable \\
\hline E10FP 9 & 10.00 & 31.00 & 26.00 & 0.32 & 0.38 & 1.19 & 16.13 & 37.32 & Fair \\
\hline KSR 1 & 10.00 & 19.00 & 14.00 & 0.53 & 0.71 & 1.36 & 26.32 & 51.55 & Poor \\
\hline KSR 2 & 10.00 & 19.00 & 18.00 & 0.53 & 0.56 & 1.06 & 5.26 & 27.19 & Excellent \\
\hline KSR 3 & 10.00 & 21.00 & 18.00 & 0.48 & 0.56 & 1.17 & 14.29 & 34.31 & Good \\
\hline KSR 4 & 10.00 & 22.00 & 16.00 & 0.45 & 0.63 & 1.38 & 27.27 & 47.5 & Poor \\
\hline KSR 5 & 10.00 & 18.00 & 15.00 & 0.56 & 0.67 & 1.20 & 16.67 & 39.25 & Fair \\
\hline KSR 6 & 10.00 & 22.00 & 15.00 & 0.45 & 0.67 & 1.47 & 31.82 & 57.86 & V Poor \\
\hline KSR 7 & 10.00 & 20.00 & 14.00 & 0.50 & 0.71 & 1.43 & 30.00 & 46.82 & Poor \\
\hline KSR 8 & 10.00 & 22.00 & 17.00 & 0.45 & 0.59 & 1.29 & 22.73 & 42.51 & Passable \\
\hline KSR 9 & 10.00 & 20.00 & 17.00 & 0.50 & 0.59 & 1.18 & 15.00 & 33.62 & Good \\
\hline
\end{tabular}


TABLE III - Physical Evaluation and assay of tizanidine matrix

\begin{tabular}{ccccccc}
\hline $\begin{array}{c}\text { Formulation } \\
\text { code }\end{array}$ & $\begin{array}{c}\text { Thickness } \\
(\mathbf{m m})\end{array}$ & $\begin{array}{c}\text { Hardness } \\
(\mathbf{k g})\end{array}$ & $\begin{array}{c}\text { Weight Variation } \\
\mathbf{( m g )}\end{array}$ & $\begin{array}{c}\text { Friablity } \\
(\mathbf{\%})\end{array}$ & $\begin{array}{c}\text { Disintegration } \\
\text { time (hrs) }\end{array}$ & $\begin{array}{c}\text { Assay } \\
(\%)\end{array}$ \\
\hline K4M 2 & $3.96 \pm 0.10$ & $4.81 \pm 0.52$ & $108.23 \pm 2.80$ & 0.76 & 4.82 & 98.76 \\
K4M 3 & $4.05 \pm 0.12$ & $4.20 \pm 0.38$ & $113.21 \pm 2.80$ & 0.91 & 4.18 & 97.25 \\
K4M 5 & $3.67 \pm 0.14$ & $3.74 \pm 0.70$ & $96.98 \pm 5.00$ & 1.14 & 3.55 & 96.38 \\
K4M 9 & $3.99 \pm 0.12$ & $4.69 \pm 1.18$ & $110.71 \pm 4.06$ & 0.94 & 4.30 & 98.05 \\
K100M 2 & $4.01 \pm 0.14$ & $5.87 \pm 0.68$ & $109.30 \pm 3.66$ & 0.57 & 6.87 & 98.37 \\
K100M 3 & $4.03 \pm 0.16$ & $4.30 \pm 0.70$ & $113.37 \pm 4.78$ & 0.85 & 4.95 & 97.82 \\
K100M 5 & $3.97 \pm 0.16$ & $4.04 \pm 1.12$ & $95.74 \pm 6.32$ & 0.99 & 3.73 & 98.61 \\
K100M 9 & $3.98 \pm 0.08$ & $5.57 \pm 0.76$ & $110.27 \pm 4.00$ & 0.63 & 6.58 & 98.87 \\
E10ST 2 & $4.01 \pm 0.15$ & $8.04 \pm 1.86$ & $113.54 \pm 3.71$ & 0.76 & 1.42 & 96.81 \\
E10ST 6 & $4.39 \pm 0.18$ & $8.53 \pm 2.26$ & $125.35 \pm 4.53$ & 0.69 & 2.10 & 97.32 \\
E19ST 9 & $4.05 \pm 0.13$ & $7.96 \pm 1.57$ & $109.85 \pm 3.82$ & 0.97 & 1.38 & 96.18 \\
E10FP 2 & $3.99 \pm 0.08$ & $12.92 \pm 1.80$ & $113.77 \pm 3.74$ & 0.30 & 5.72 & 98.79 \\
E10FP 3 & $4.00 \pm 0.10$ & $11.75 \pm 2.14$ & $109.46 \pm 4.5$ & 0.95 & 3.68 & 96.32 \\
E10FP 9 & $3.98 \pm 0.14$ & $12.57 \pm 2.30$ & $110.82 \pm 5.38$ & 0.47 & 5.13 & 98.24 \\
KSR 2 & $4.24 \pm 0.10$ & $5.01 \pm 0.74$ & $113.30 \pm 3.04$ & 0.29 & 7.52 & 98.39 \\
KSR 3 & $4.07 \pm 0.14$ & $4.24 \pm 0.88$ & $118.97 \pm 3.98$ & 0.84 & 4.25 & 96.51 \\
KSR 5 & $4.04 \pm 0.12$ & $3.40 \pm 0.78$ & $96.82 \pm 5.28$ & 1.53 & 3.15 & 95.23 \\
KSR 9 & $4.20 \pm 0.12$ & $4.20 \pm 0.58$ & $116.05 \pm 4.04$ & 0.63 & 6.27 & 97.27 \\
\hline
\end{tabular}

concentration of polymers was unable to control tablet disintegration upto 4 hours. It was also observed that tablets formulated with Ethocel 10 Standard grade were unable to control the disintegration that may be due to their larger particle size which allows water to penetrate inside the void spaces as reported by Crowley et al. (2004). Assay of all compressed formulations were within the limits as specified in USP (USP35-NF30, 2012).

\section{Study of hydration behavior}

Swelling studies revealed the swelling properties of tablets and studied as a function of polymers used in the study. The swelling behavior of a polymer enables the formation of swellable layer or the gel layer. The gel layer hindered movement of drug from inner dry layer and enable the release of drug only from the upper gel layer and causing a controlled release of drug. Formulations containing hydrophilic polymers swell well while the hydrophobic polymers showed less swelling behavior.

The results of swelling behavior with different polymers were shown in Figure 1. It is clear from the results that HPMC showed highest hydration ability as compared to Kollidon SR and Ethocel due to its hydrophilic nature. Formulation containing Ethocel showed least swelling among three tested polymers due to its higher hydrophobic nature. The data showed that by increasing the quantity of HPMC K4M and K100M, tablet swelling has been increased. Nerurkar et al., also noticed that increase in concentration of polymer in matrix will cause an increase of amount of water uptake (Nerurkar et al., 2005). Further, from these results it is also clear that with change of HPMC viscosity grade to higher side, swelling properties also enhanced.

\section{In vitro drug release profiles}

Tizanidine formulations release profiles in $0.1 \mathrm{~N}$ $\mathrm{HCl}$, phosphate buffer $\mathrm{pH} 4.5$ and 6.8 were presented in Figure 2, 3 and 4, respectively. Release profiles of tizanidine tablets in different dissolution media were not found significantly different. Amir and Ahmad (2010), also found the similar type of drug release behavior of tizanidine and tramadol modified release microparticles in $0.1 \mathrm{~N} \mathrm{HCl}$ and $\mathrm{pH} 6.8$ phosphate buffer. It was found that formulations with Ethocel 10 standard grade were unable to control the release and nearly the entire drug has been released within 4 hours in the three dissolution media. According to Percolation theory, in a matrix formulation of hydrophilic drug and hydrophobic polymer, drug release 

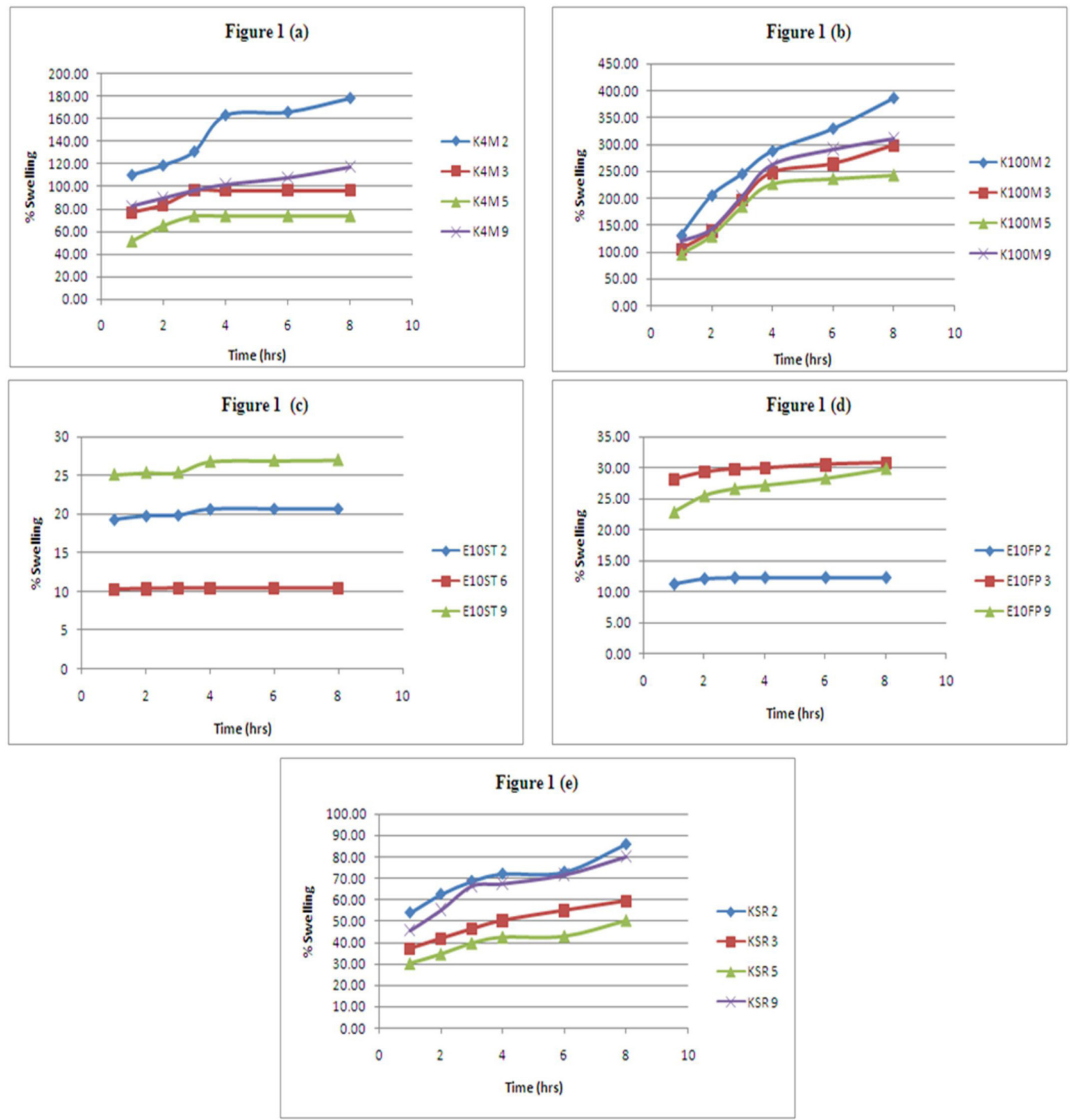

FIGURE 1 - Hydration behavior of tizanidine matrix formulations containing (a) HPMC K4M (b) HPMC K100M (c) Ethocel 10ST (d) Ethocel 10 FP (e) Kollidon SR.

was derived by dissolution of drug through capillaries composed of interconnecting drug particle cluster and pore network (Holman, Leuenberger, 1988). With more ethyl cellulose particles fewer pore networks were formed (Crowley et al., 2004) as the case with fine particles and retard the release while in case of coarser particles the more pore network will be formed that was unable to control the release of drug.

Formulations containing $25 \%$ or less of polymer (K4M5, K100M5, E10FP3 and KSR5) were also unable to retard the release and more than $90 \%$ of drug was available in dissolution media in 4 hours. Tablets with a polymer ratio of $30 \%$ (K4M3, K100M3 and KSR3) released about $80 \%$ of drug except in case of Ethocel 10 FP (E10FP9) where 76\% release was observed with $30 \%$ of polymer. K100M9 (HPMC K100M: 40\% polymer) given a good controlled release profile. From K100M9 formulation, around $40 \%$ drug released in $4 \mathrm{~h}, 80 \%$ in $8 \mathrm{~h}$ and $98 \%$ in 24 hours. Similar type of profiles were observed in formulations K4M2 (50\% polymer), E10FP2 ( $40 \%$ polymer) and KSR 2 (55\% polymer) in which around 45 to $53 \%$ drug released in 4 hours was observed, 82 to 

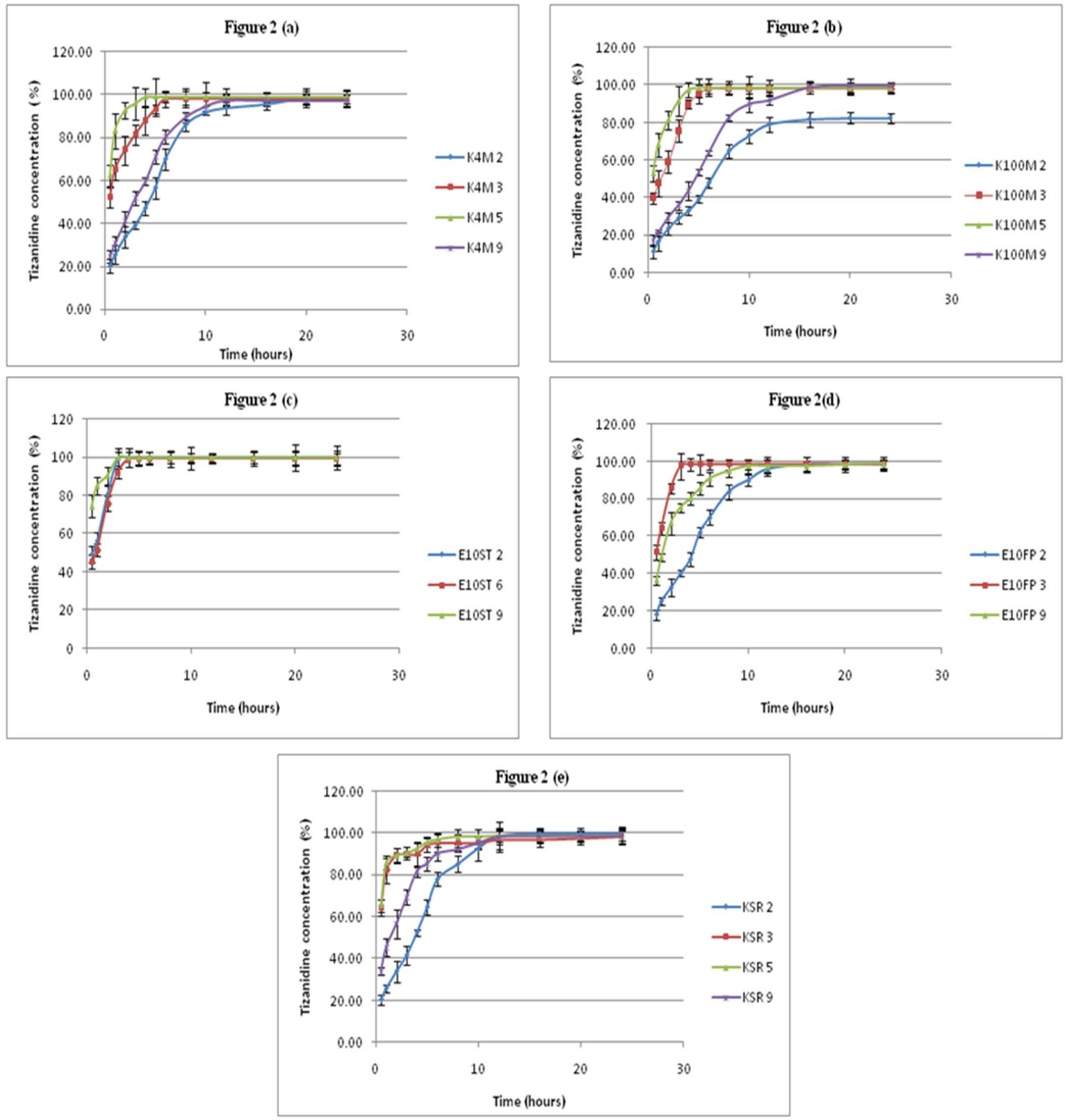

FIGURE 2 - Drug release profiles of Tizanidine formulations in $0.1 \mathrm{~N} \mathrm{HCl}$ containing (a) HPMC K4M (b) HPMC K100M (c) Ethocel 10ST (d) Ethocel 10FP (e) Kollidon SR.

$85 \%$ drug released in 8 hours and 94 to $99 \%$ drug released in 24 hours. It was observed in all formulations that drug release has inverse relation with polymer concentration. Barakat, Elbagory and Almurshedi (2009) found that increase in the concentration of HPMC results in reduction in the release rate from carbamazepine matrix formulation and followed non-fickian diffusion which shifted to case II with the increase in HPMC ratio in formulation, showed significant contribution through erosin. Similarly, Baviskar, Sharma and Jain (2013) observed retard release of verapamil hydrochloride matrix tablet with increase in concentration of HPMC K15M and Eudragit RSPO. Reza, Quadir and Haider (2003) found increase in drug release rate with decreasing total polymeric content of matrix tablets of theophylline, diclofenac sodium and diltiazem hydrochloride by using plastic, hydrophobic and hydrophilic polymers. The release rate was much retarded in formulation $\mathrm{K} 100 \mathrm{M} 2$ which contains $50 \%$ of polymer and around $80 \%$ of the drug release in 24 hours. Huang et al. (2004) had similar finding where release was incomplete from propranalol hydrochloride tablet containing high amount of HPMC. 

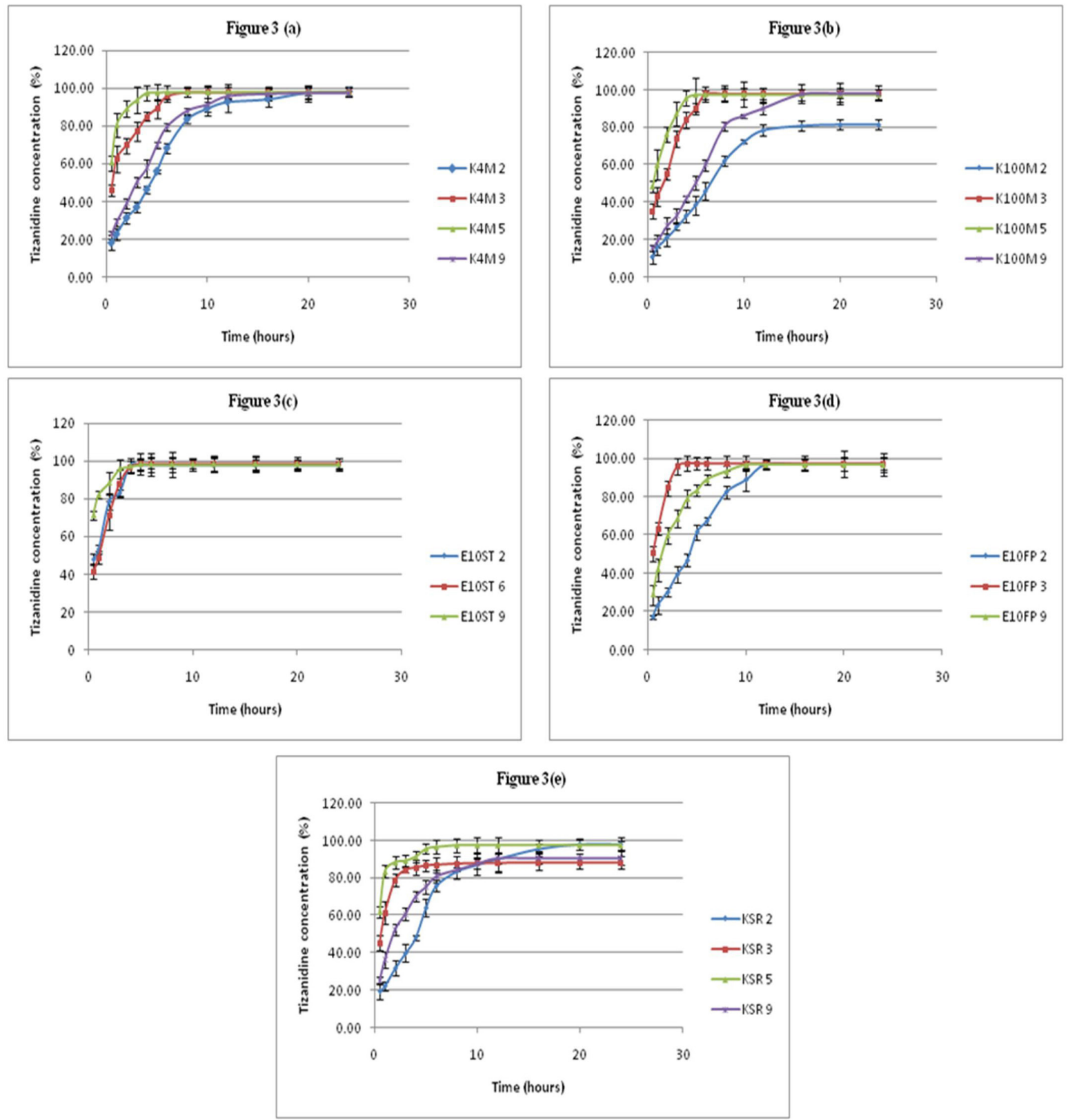

FIGURE 3 - Drug release profiles of tizanidine formulations in phosphate buffer pH 4.5 containing (a) HPMC K4M (b) HPMC K100M (c) Ethocel 10ST (d) Ethocel 10FP (e) Kollidon SR.

\section{Drug release kinetics}

\section{Model dependent method}

Drug release kinetics from tizanidine matrix tablets was described by various mathematical models and equations. The dissolution data was fitted to zero order, first order, Higuchi, Korsmeyer-Peppas and Hixon-Crowell to determine the mechanism of drug release. The Regression coefficients and release constants were calculated by DD-solver and shown in Table IV. DD Solver is an add-in program for Microsoft Excel $^{\circledR}$ for dissolution data modeling and profile comparison (Zhang et al., 2010b). The dissolution data up to 8 hours were used for all formulations. The data selection was based on the data until the time which represent the dynamics of dissolution process (Polli et al., 1997). The tizanidine formulations which were best support the zero order release kinetics were K4M2, K100M9, E10FP2 and KSR2 as highest linearity values were observed in $0.1 \mathrm{~N} \mathrm{HCl}$, phosphate buffer $\mathrm{pH} 4.5$ and 6.8. Formulation, K100M2 although yielded zero-order but incomplete release kinetics. Bravo, Lamas and 

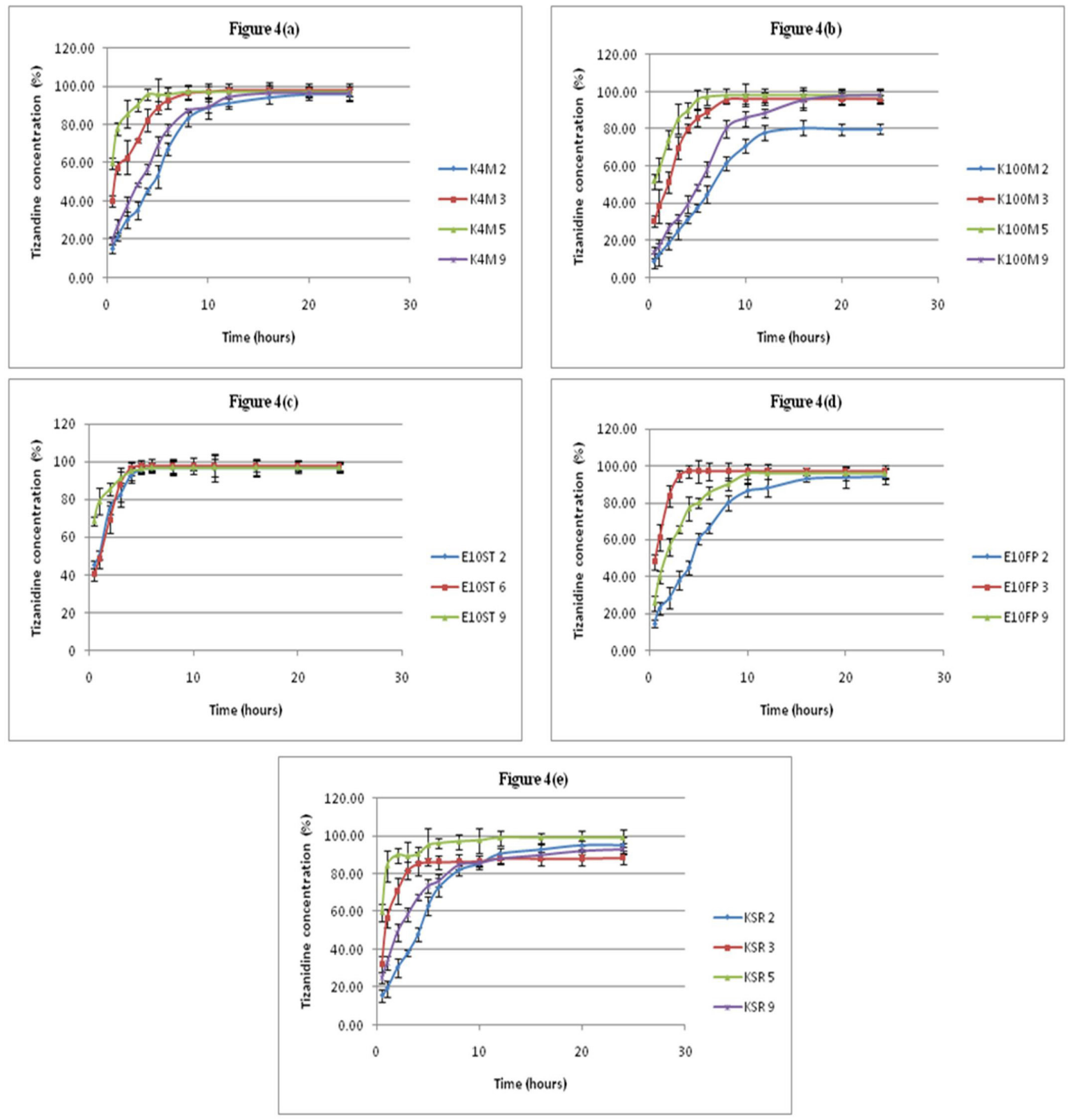

FIGURE 4 - Drug release profiles of tizanidine formulations in phosphate buffer pH 6.8 containing (a) HPMC K4M (b) HPMC K100M (c) Ethocel 10ST (d) Ethocel 10FP (e) Kollidon SR.

Salomon (2002) found zero order release kinetics for diclofenac sodium HPMC matrix tablets with highest regression coefficient values followed by Higuchi and first order. Sankalia Sankalia, Mashru (2008) have formulated glipizide matrix tablets with xanthan:MCC PH301 and xanthan:HPMC K4M:Starch 1500 with Korsmeyer-Peppas' and zero-order release mechanism, respectively. Jan et al. (2011) successfully developed sustained release Ketoprofen tablets with different grades of Ethocel FP and found release kinetics nearly zeroorder. Sahoo et al. (2008) prepared controlled release propranalol hydrochloride tablet by direct compression with $40 \%$ Kollidon SR that showed a zero-order release kinetics.

The diffusional coefficient (n) obtained from Korsmeyers equation were in the range of $>0.45$ to $<0.89$ for K4M2, K100M9, E10FP2 and KSR2 which showed that drug was release through anomalous transport also known as non-Fickian release that was an indication that the release of drug is controlled by both diffusion and erosion mechanism (Peppas, 1985). This equation has also been used by many researchers 
TABLE IV - Model dependent assessment of tizanidine formulations

\begin{tabular}{|c|c|c|c|c|c|c|c|c|c|c|c|}
\hline & \multicolumn{2}{|c|}{ Zero order } & \multicolumn{2}{|c|}{ First order } & \multicolumn{2}{|c|}{ Higuchi } & \multicolumn{3}{|c|}{ Korsmeyer-Peppas } & \multicolumn{2}{|c|}{ Hixon-crowell } \\
\hline & $r^{2}$ & $K_{0}\left(h^{-1}\right)$ & $r^{2}$ & $K_{l}\left(h^{-1}\right)$ & $r^{2}$ & $K_{H}\left(h^{-1 / 2}\right)$ & $r^{2}$ & $n$ & $K_{\mathrm{kp}}\left(h^{-\mathrm{n}}\right)$ & $r^{2}$ & $K_{\mathrm{HC}}\left(h^{-1 / 3}\right)$ \\
\hline \multicolumn{12}{|l|}{$0.1 \mathrm{~N} \mathrm{HCl}$} \\
\hline K4M 2 & 0.996 & 11.586 & 0.964 & 0.192 & 0.972 & 26.792 & 0.982 & 0.641 & 21.498 & 0.976 & 0.055 \\
\hline K4M 3 & 0.930 & 17.217 & 0.951 & 0.923 & 0.978 & 42.347 & 0.991 & 0.226 & 63.683 & 0.974 & 0.180 \\
\hline K4M 9 & 0.992 & 13.355 & 0.984 & 0.259 & 0.994 & 31.333 & 0.994 & 0.526 & 30.089 & 0.992 & 0.072 \\
\hline K100M 2 & 0.994 & 8.310 & 0.977 & 0.115 & 0.971 & 19.058 & 0.985 & 0.726 & 13.342 & 0.983 & 0.034 \\
\hline K100M 3 & 0.927 & 16.894 & 0.972 & 0.566 & 0.970 & 40.719 & 0.976 & 0.358 & 50.441 & 0.980 & 0.146 \\
\hline K100M 9 & 0.997 & 10.830 & 0.969 & 0.170 & 0.971 & 24.870 & 0.986 & 0.713 & 17.794 & 0.979 & 0.049 \\
\hline E10FP 2 & 0.996 & 11.653 & 0.978 & 0.195 & 0.983 & 26.959 & 0.990 & 0.642 & 21.589 & 0.987 & 0.056 \\
\hline E10FP 9 & 0.927 & 15.951 & 0.995 & 0.526 & 0.978 & 38.660 & 0.989 & 0.325 & 50.353 & 0.991 & 0.139 \\
\hline KSR 2 & 0.991 & 12.287 & 0.975 & 0.215 & 0.981 & 28.472 & 0.987 & 0.629 & 23.277 & 0.985 & 0.061 \\
\hline KSR 3 & 0.778 & 17.573 & 0.979 & 1.821 & 0.862 & 44.177 & 0.919 & 0.117 & 77.467 & 0.936 & 0.191 \\
\hline KSR 9 & 0.938 & 15.559 & 0.991 & 0.449 & 0.981 & 37.471 & 0.987 & 0.363 & 46.104 & 0.996 & 0.119 \\
\hline \multicolumn{12}{|l|}{ pH 4.5 } \\
\hline K4M 2 & 0.997 & 11.257 & 0.971 & 0.182 & 0.975 & 25.919 & 0.988 & 0.686 & 19.373 & 0.982 & 0.052 \\
\hline K4M 3 & 0.941 & 16.764 & 0.959 & 0.732 & 0.982 & 40.997 & 0.991 & 0.257 & 58.960 & 0.965 & 0.171 \\
\hline K4M 9 & 0.990 & 13.075 & 0.986 & 0.250 & 0.993 & 30.579 & 0.994 & 0.554 & 28.138 & 0.993 & 0.069 \\
\hline K100M 2 & 0.997 & 7.971 & 0.982 & 0.108 & 0.973 & 18.242 & 0.988 & 0.749 & 12.322 & 0.988 & 0.033 \\
\hline K100M 3 & 0.944 & 16.422 & 0.981 & 0.487 & 0.981 & 39.311 & 0.984 & 0.401 & 45.674 & 0.987 & 0.127 \\
\hline K100M 9 & 0.996 & 10.326 & 0.969 & 0.156 & 0.968 & 23.606 & 0.987 & 0.761 & 15.623 & 0.979 & 0.046 \\
\hline E10FP 2 & 0.996 & 11.393 & 0.980 & 0.187 & 0.983 & 26.297 & 0.991 & 0.664 & 20.350 & 0.989 & 0.054 \\
\hline E10FP 9 & 0.937 & 15.397 & 0.998 & 0.425 & 0.983 & 36.938 & 0.990 & 0.392 & 43.513 & 0.997 & 0.113 \\
\hline KSR 2 & 0.989 & 11.920 & 0.973 & 0.202 & 0.976 & 27.493 & 0.985 & 0.673 & 20.987 & 0.982 & 0.057 \\
\hline KSR 3 & 0.784 & 16.026 & 0.997 & 0.825 & 0.879 & 39.806 & 0.927 & 0.202 & 61.979 & 0.981 & 0.171 \\
\hline KSR 9 & 0.944 & 13.861 & 0.999 & 0.318 & 0.987 & 33.152 & 0.991 & 0.411 & 37.952 & 0.996 & 0.085 \\
\hline \multicolumn{12}{|l|}{ pH 6.8} \\
\hline K4M 2 & 0.997 & 10.986 & 0.972 & 0.173 & 0.975 & 25.181 & 0.989 & 0.733 & 17.455 & 0.982 & 0.050 \\
\hline K4M 3 & 0.948 & 16.217 & 0.968 & 0.561 & 0.983 & 39.362 & 0.989 & 0.302 & 53.009 & 0.968 & 0.144 \\
\hline K4M 9 & 0.990 & 12.811 & 0.990 & 0.237 & 0.996 & 29.837 & 0.997 & 0.591 & 25.898 & 0.996 & 0.066 \\
\hline K100M 2 & 0.998 & 7.769 & 0.985 & 0.104 & 0.974 & 17.638 & 0.994 & 0.836 & 10.336 & 0.990 & 0.031 \\
\hline K100M 3 & 0.949 & 15.577 & 0.991 & 0.412 & 0.985 & 37.135 & 0.988 & 0.430 & 41.332 & 0.995 & 0.109 \\
\hline K100M 9 & 0.995 & 10.075 & 0.969 & 0.149 & 0.967 & 22.928 & 0.988 & 0.812 & 13.960 & 0.978 & 0.044 \\
\hline E10FP 2 & 0.994 & 11.092 & 0.982 & 0.179 & 0.984 & 25.538 & 0.992 & 0.689 & 19.001 & 0.989 & 0.051 \\
\hline E10FP 9 & 0.935 & 14.844 & 0.999 & 0.381 & 0.982 & 35.546 & 0.988 & 0.406 & 41.007 & 0.997 & 0.101 \\
\hline KSR 2 & 0.992 & 11.578 & 0.983 & 0.191 & 0.984 & 26.576 & 0.992 & 0.719 & 18.845 & 0.990 & 0.055 \\
\hline KSR 3 & 0.797 & 15.700 & 0.985 & 0.610 & 0.889 & 38.587 & 0.925 & 0.272 & 54.335 & 0.980 & 0.156 \\
\hline KSR 9 & 0.959 & 13.485 & 0.999 & 0.291 & 0.993 & 32.119 & 0.995 & 0.433 & 35.555 & 0.998 & 0.078 \\
\hline
\end{tabular}

to identify the release mechanism of drug. Savaşer et al. used the same application for drug release mechanism evaluation from diclofenac sodium containing HPMC matrices (Savaşer, Özkan, Işmer, 2005), Roni, Kibria and
Jalil (2009) applied equation for evaluation of controlled release alfuzosin tablets prepared with ethylcellulose and hydropropylmethylcellulose. El-Bagory et al. (2012) relate Korsmeyer-Peppas equation for release mechanism 
TABLE V - Similarity Factor $\left(f_{2}\right)$ Values of Tizanidine formulations

\begin{tabular}{lcccc}
\hline \multirow{2}{*}{ Comparision } & \multicolumn{2}{c}{$\boldsymbol{f}_{\mathbf{2}}$} & \multirow{2}{*}{ Dissolution Profile } \\
\cline { 2 - 4 } & $0.1 \mathrm{~N} \mathrm{HCl}$ & $\mathrm{pH} 4.5$ & $\mathrm{pH} \mathrm{6.8}$ & Similar \\
K100M9 and K4M2 & 69.28 & 65.69 & 65.80 & Dissimilar \\
K100M9 and K4M3 & 20.42 & 20.96 & 22.44 & Dissimilar \\
K100M9 and K4M9 & 43.66 & 42.05 & 42.22 & Dissimilar \\
K100M9 and K100M2 & 47.22 & 48.88 & 49.19 & Dissimilar \\
K100M9 and K100M3 & 23.73 & 24.33 & 26.37 & Similar \\
K100M9 and E10FP2 & 66.04 & 60.97 & 59.94 & Dissimilar \\
K100M9 and E10FP9 & 26.00 & 27.33 & 28.24 & Similar \\
K100M9 and KSR2 & 55.27 & 53.27 & 54.19 & Dissimilar \\
K100M9 and KSR3 & 16.57 & 20.68 & 21.93 & Dissimilar \\
K100M9 and KSR9 & 28.13 & 33.48 & 34.45 &
\end{tabular}

TABLE VI - Stability studies and shelf life of Controlled release tizanidine formulations

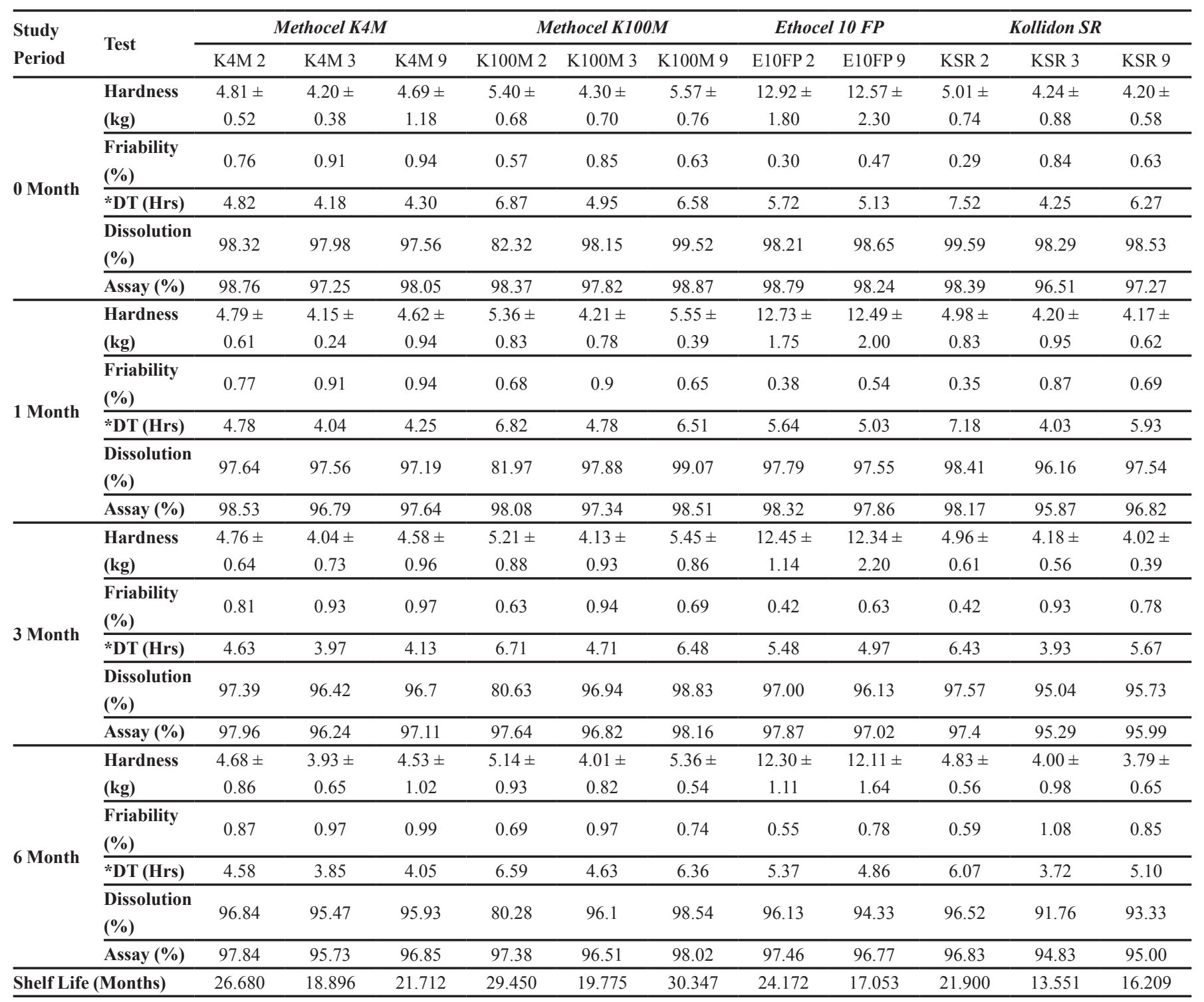


determination of theophylline matrix tablets prepared with Kollidon SR, Carnauba wax and ethylcellulose.

\section{Model independent method}

Formulation K100M9 was considered as reference and $f_{2}$ similarity test was performed for selected formulations. Dissolution profile was found to be similar for K4M2, E10FP2 and KSR2 (Table V). Comparison of dissolution profiles of drug through similarity test $\left(f_{2}\right)$ was used in other research studies for SR preparations (Dash et al., 2010; Shoaib et al., 2010; Salústio et al., 2011).

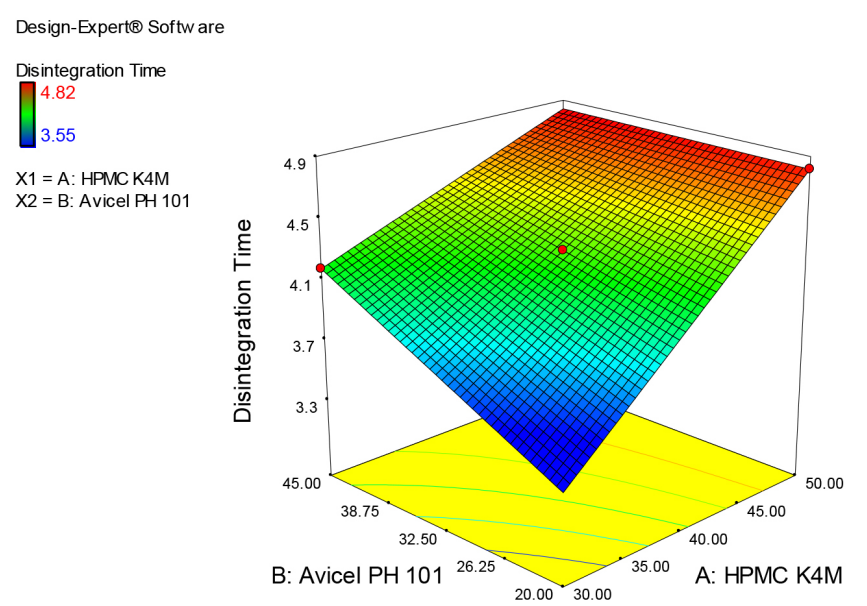

FIGURE 5a - Response surface model (RSM) showing effect of independent variables HPMC K4M and Avicel pH 101 on Disintegration time.

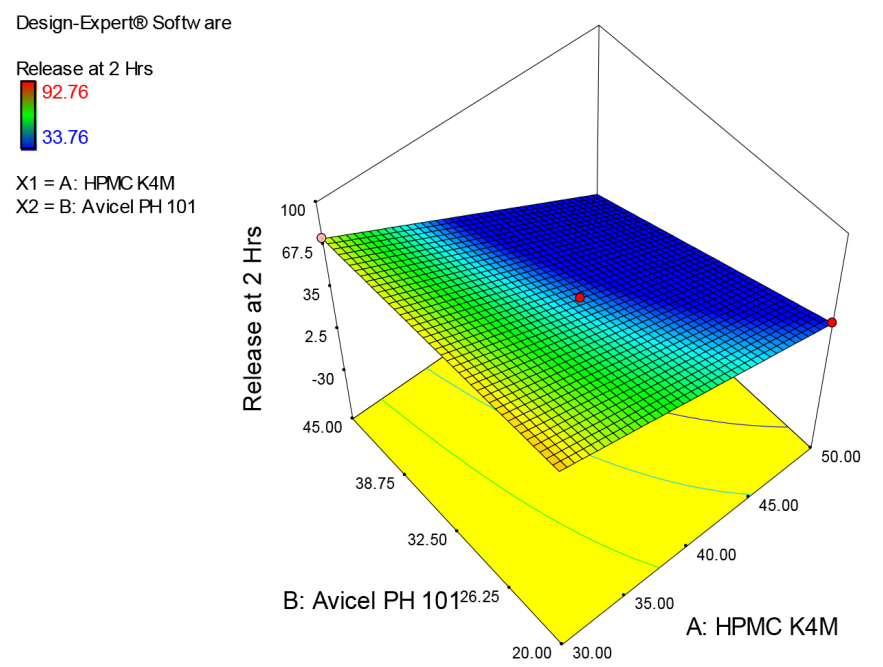

FIGURE 5b - Response surface model (RSM) showing effect of independent variables HPMC K4M and Avicel pH 101 on responses Drug release in 2 hours.

\section{Response surface analysis}

Response surface models of effect of HPMC K4M and Avicel pH 101 are shown in Figure 5a, 5b and 5c. The $3 \mathrm{D}$ plots clearly showed that polymer had greater influence on response as compared to Avicel pH 101. Disintegration time increased drastically with an increase in polymer concentration while Avicel has lesser effect in enhancing disintegration time as compare to HPMC K4M. Increase in HPMC K4M ratio in the formulation caused a steep decrease in the release in 2 hours and Avicel seems to produce not a very significant impact on matrix release.

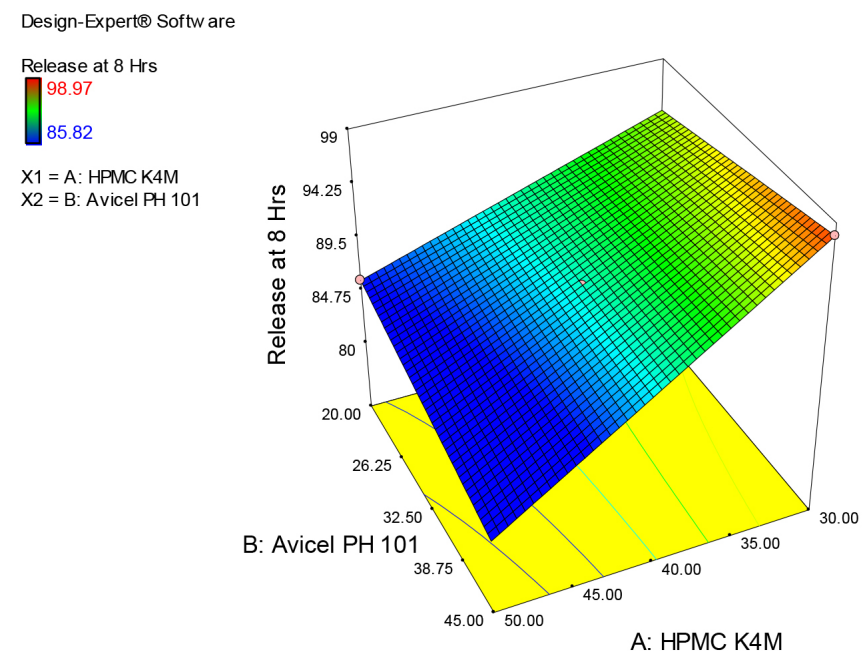

FIGURE 5c - Response surface model (RSM) showing effect of independent variables HPMC K4M and Avicel pH 101 on Drug release in 8 hours.

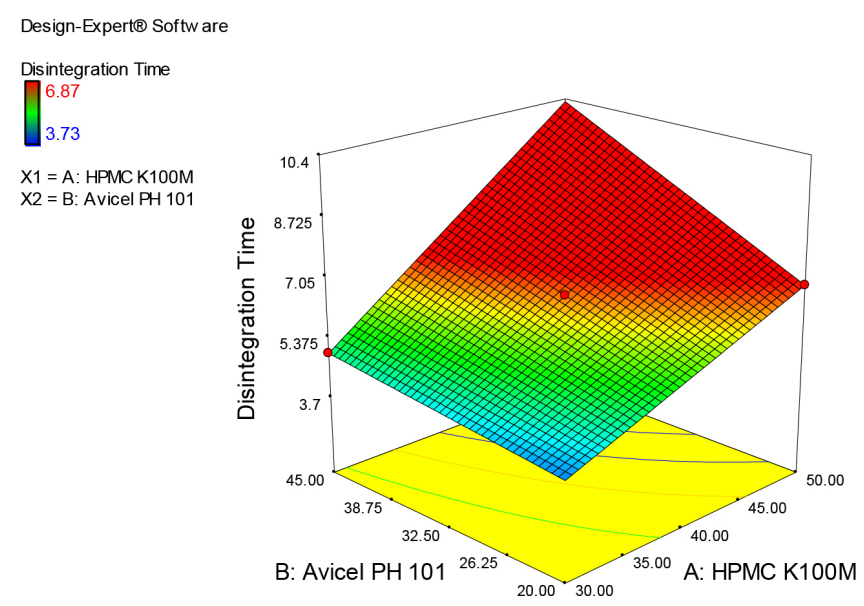

FIGURE 6a - Response surface model (RSM) showing effect of independent variables HPMC K100M and Avicel pH 101 on Disintegration time. 


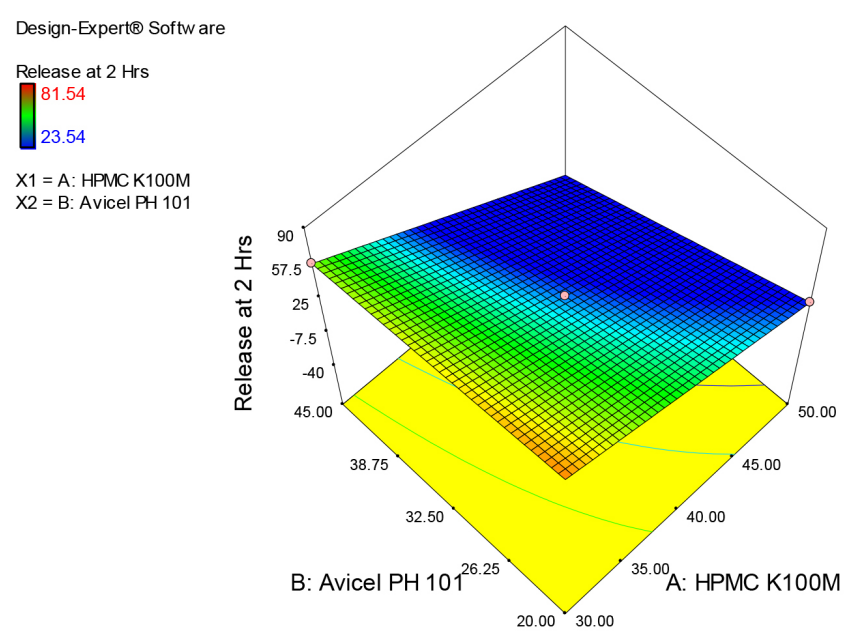

FIGURE 6b - Response surface model (RSM) showing effect of independent variables HPMC K100M and Avicel pH 101 on Drug release in 2 hours.

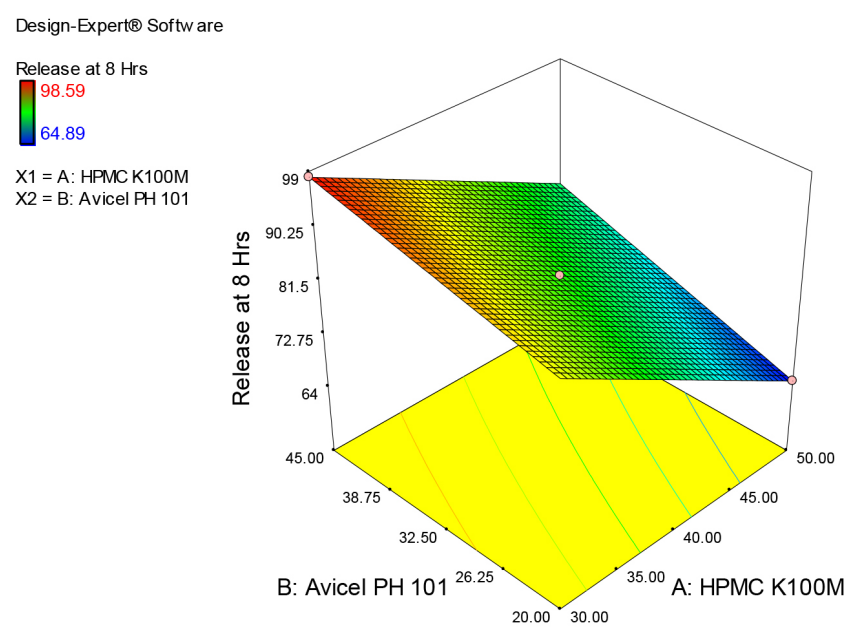

FIGURE 6c - Response surface model (RSM) showing effect of independent variables HPMC K100M and Avicel pH 101 on Drug release in 8 hours.

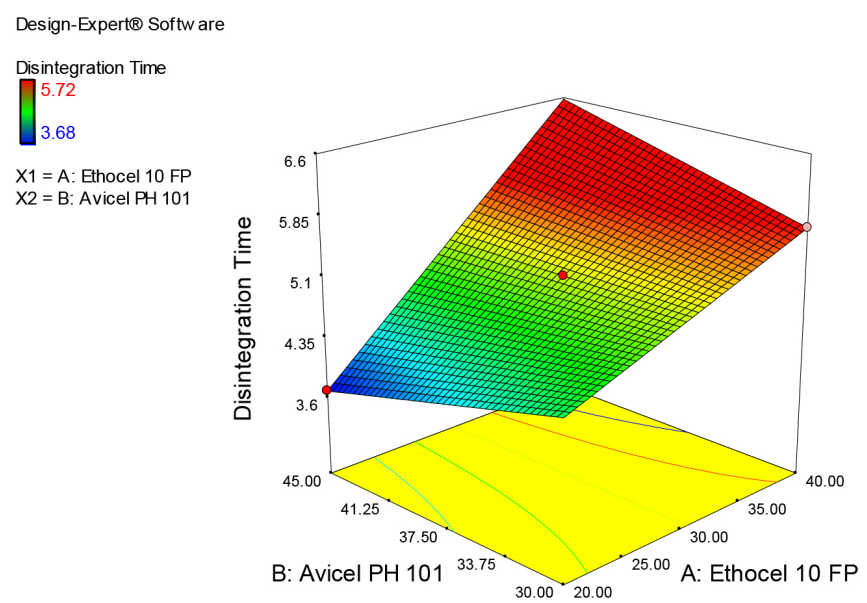

FIGURE 7a - Response surface model (RSM) showing effect of independent variables Ethocel 10FP and Avicel pH 101 on Disintegration time.

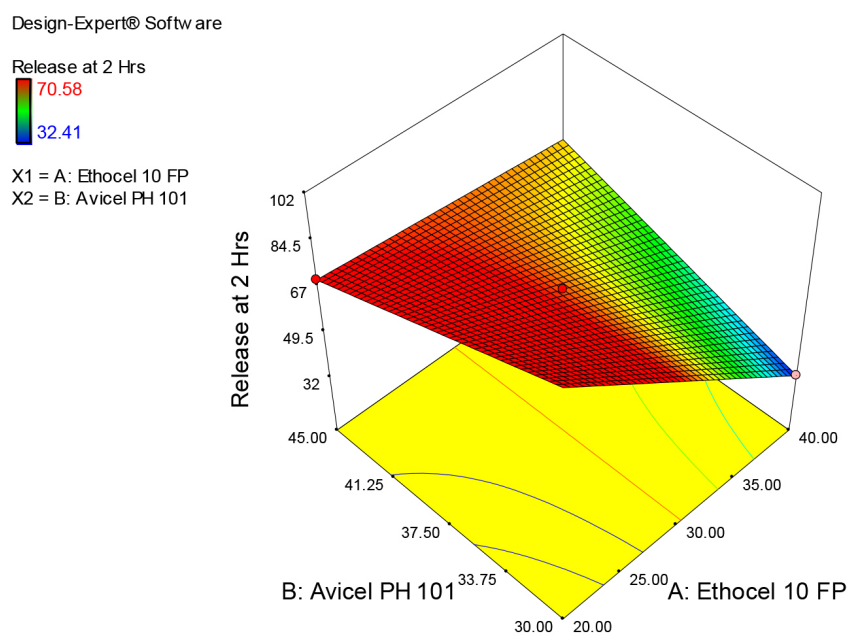

FIGURE 7b - Response surface model (RSM) showing effect of independent variables Ethocel 10FP and Avicel pH 101 on Drug release in 2 hours.

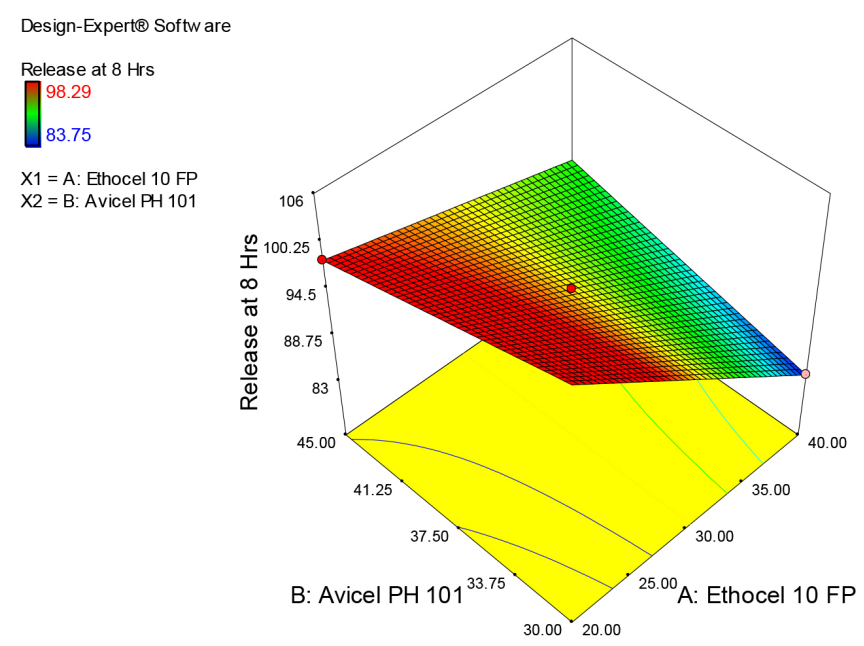

FIGURE 7c - Response surface model (RSM) showing effect of independent variables Ethocel 10FP and Avicel pH 101 on Drug release in 8 hours.

At 8 hours, no prominent effect on release can be seen with HPMC K4M change and a near to linear response found with change in Avicel pH101. Similar responses were observed with HPMC K100M for disintegration time and release at 2 hours while release at 8 hours has been significantly influenced with increase in HPMC K100M as presented in Figure 6a, 6b and 6c. RSM for Ethocel $10 \mathrm{FP}$ effect on responses were shown in Figure 7. It can be clearly seen that increase in concentration of polymer caused an increase in disintegration time and Avicel did not produce any significant change in disintegration time (Figure $7 \mathrm{a}, 7 \mathrm{~b}$ and $7 \mathrm{c}$ ). There was a declining response in release of the drug at 2 hours and 8 hours with an increase 


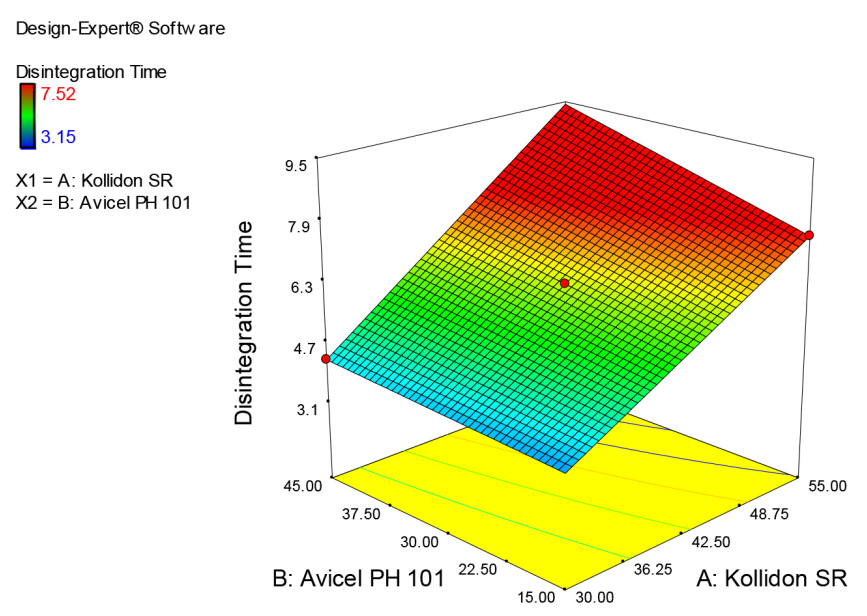

FIGURE 8a - Response surface model (RSM) showing effect of independent variables Kollidon SR and Avicel pH 101 on Disintegration time.

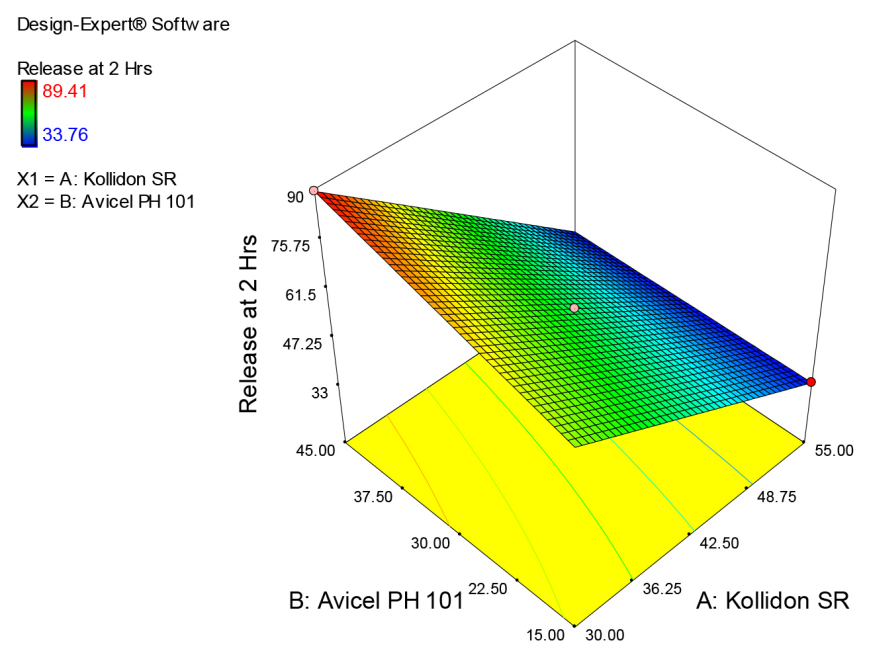

FIGURE 8b - Response surface model (RSM) showing effect of independent variables Kollidon SR and Avicel pH 101 on Drug release in 2 hours.

in Ethocel 10FP proportion in the formulation (Figure $7 \mathrm{~b}$ and $7 \mathrm{c}$ ). Kollidon SR produced expected response of increase in disintegration time with increase in polymer concentration. An inverse relationship found between Kollidon SR proportion and release at 2 and 8 hours (Figure $8 \mathrm{~b}$ and 8c). Bose, Wong and Singh (2012) found similar type of effect of HPMC K100M on Itopride SR matrix tablet release.

\section{Stability evaluation}

The formulations showing disintegration time greater than 4 hours were subjected to accelerated stability studies for $0,1,3$ and 6 months following ICH guidelines

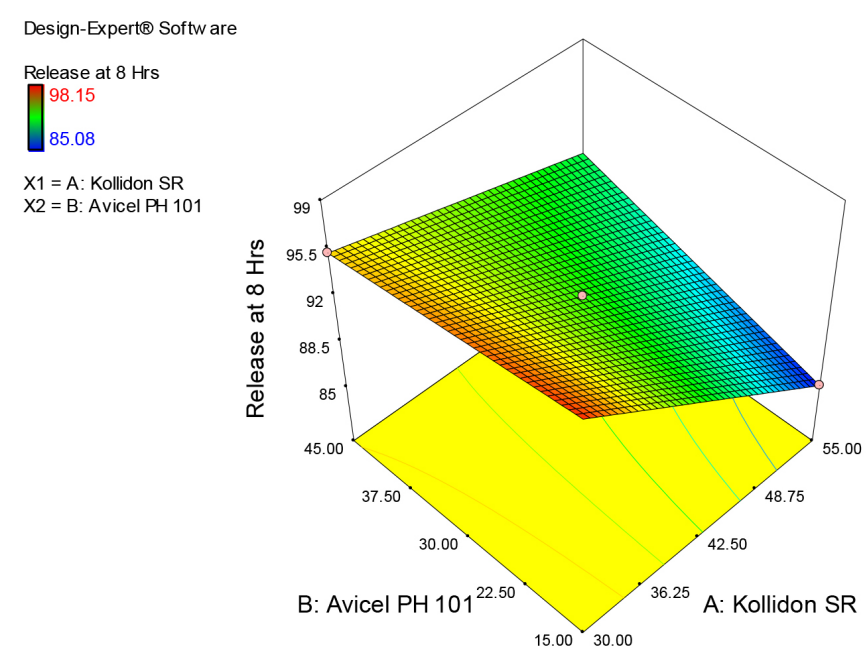

FIGURE 8c - Response surface model (RSM) showing effect of independent variables Kollidon SR and Avicel pH 101 on Drug release in 8 hours.

(ICH, 2003). Formulation K4M2, K4M3, K4M9, K100M2, K100M3, K100M9, E10FP2, E10FP9, KSR2, KSR3 and KSR9 were evaluated for quality attribute, shelf life were calculated using software R-Gui version 2.15.2 (stab) and results were given in Table VI. It was found that all formulations were within the acceptable limits for physical and chemical parameter but formulations K4M3 and KSR3 were failed for disintegration time and friability. It was found that formulations K4M2, K100M2, K100M9 (highest shelf life: 30.347 months) and E10FP2 had the shelf life of more than 24 months and were considered as stable formulations.

\section{CONCLUSION}

Tizanidine hydrochloride formulations with controlled release characteristics were prepared by using HPMC K4M and K100M, Ethocel 10FP and Kollidon SR.

It was observed that the formulations with polymer contents lesser than $40 \%$ remained ineffective in controlling the release of drug however, satisfactory release profiles were obtained with HPMC K4M (K4M2) 50\%, K100M (K100M9) 40\%, Ethocel 10FP (E10FP2) $40 \%$ and Kollidon SR (KSR2) 55\%. Formulation K100M9 with HPMC K100M showed highest shelf life of 30.347 months. Therefore, it can be concluded that controlled release tizanidine hydrochloride tablets can effectively be prepared by using these polymers through direct compression method. Moreover, formulation K100M9 was found to be the best formulation for controlled release tizanidine. 


\section{REFERENCES}

AAMIR, M.N.; AHMAD, M. Production and stability evaluation of modified-release microparticles for the delivery of drug combinations. AAPS PharmSciTech, v.11, n.1, p.351-355, 2010.

BARAKAT, N.S.; ELBAGORY, I.M.; ALMURSHEDI, A.S. Controlled-release carbamazepine matrix granules and tablets comprising lipophilic and hydrophilic components. Drug Deliv., v.16, n.1, p.57-65, 2009.

BAVISKAR, D.; SHARMA, R.; JAIN, D. Modulation of drug release by utilizing $\mathrm{pH}$-independent matrix system comprising water soluble drug verapamil hydrochloride. Pak. J. Pharm. Sci., v.26, n.1, p.137, 2013.

BOSE, A.; WONG, T.W.; SINGH, N. Formulation development and optimisation of sustained release matrix tablet of itopride hel by response surface methodology and its evaluation of release kinetics. Saudi Pharm. J., v.21, n.2, p.201-213, 2012.

BOX, G.E.; HUNTER, J.S. Multi-factor experimental designs for exploring response surfaces. Ann. Math. Statist., v.28, n.1, p.195-241, 1957.

BOX, G.E.; WILSON, K. On the experimental attainment of optimum conditions. J. Roy. Stat. Soc. B-stat. Met., v.13, n.1, p.1-45, 1951.

BRAVO, S.A.; LAMAS, M.C.; SALOMON, C.J. Invitro studies of diclofenac sodium controlled-release from biopolymeric hydrophilic matrices. J. Pharm. Pharm. Sci., v.5, n.3, p.213$219,2002$.

CAO, Q.R.; CHOI, Y.W.; CUI, J.H.; LEE, B.J. Formulation, release characteristics and bioavailability of novel monolithic hydroxypropylmethylcellulose matrix tablets containing acetaminophen. J. Control. Release, v.108, n.23, p.351-361, 2005.

CHIANG, W.D.; CHANG, S.W.; SHIEH, C.J. Studies on the optimized lipase-catalyzed biosynthesis of cis-3-hexen-1-yl acetate in n-hexane. Process Biochem., v.38, n.8, p.11931199, 2003.

COSTA, P.; SOUSA LOBO, J.M. Modeling and comparison of dissolution profiles. Eur. J. Pharm. Sci., v.13, n.2, p.123$133,2001$.
CROWLEY, M.M.; SCHROEDER, B.; FREDERSDORF, A.; OBARA, S.; TALARICO, M.; KUCERA, S.; MCGINITY, J.W. Physicochemical properties and mechanism of drug release from ethyl cellulose matrix tablets prepared by direct compression and hot-melt extrusion. Int. J. Pharm., v.269, n.2, p.509-522, 2004.

DASH, S.; MURTHY, P.N.; NATH, L.; CHOWDHURY, P. Kinetic modeling on drug release from controlled drug delivery systems. Acta Pol. Pharm., v.67, n.3, p.217-223, 2010.

DAVIES, P.N.J.M.N. Pharmaceutical powder compaction technology. New York: Marcel Dekker, 1995. 358 p.

DRAGANOIU, E.; ANDHERIA, M.; SAKR, A. Evaluation of the new polyvinylacetate/povidone excipient for matrix sustained release dosage forms. Pharmazeutische Industrie, v.63, n.6, p.624-629, 2001.

DAVID, W.B. Pharmacokinetics: in modern pharmaceutics. New York: MarcelDekker, 2002. v.4, p.66-91.

EL-BAGORY, I.; BARAKAT, N.; IBRAHIM, M.A.; ELENAZI, F. Formulation and in vitro evaluation of theophylline matrix tablets prepared by direct compression: effect of polymer blends. Saudi Pharm. J., v.20, n.3, p.229$238,2012$.

HAMSAVENI, D.; PRAPULLA, S.; DIVAKAR, S. Response surface methodological approach for the synthesis of isobutyl isobutyrate. Process Biochem., v.36, n.11, p.11031109, 2001.

HAO, J.; WANG, F.; WANG, X.; ZHANG, D.; BI, Y.; GAO, Y.; ZHAO, X.; ZHANG, Q. Development and optimization of baicalin-loaded solid lipid nanoparticles prepared by coacervation method using central composite design. Eur. J. Pharm. Sci., v.47, n.2, p.497-505, 2012.

HIGUCHI, T. Mechanism of sustained-action medication. Theoretical analysis of rate of release of solid drugs dispersed in solid matrices. J. Pharm. Sci., v.52, n.12, p.1145-1149, 1963.

HIXSON, A.; CROWELL, J. Dependence of reaction velocity upon surface and agitation. Ind. Eng. Chem., v.23, n.8, p.923-931, 1931. 
HOLMAN, L.; LEUENBERGER, H. The relationship between solid fraction and mechanical properties of compacts - the percolation theory model approach. Int. J. Pharm., v.46, n.1, p.35-44, 1988 .

HUANG, Y.B.; TSAI, Y.H.; YANG, W.C.; CHANG, J.S.; WU, P.C. Optimization of sustained-release propranolol dosage form using factorial design and response surface methodology. Biol. Pharm. Bull., v.27, n.10, p.1626-1629, 2004.

INTERNATIONAL CONFERENCE ON HARMONISATION. Harmonised Tripartite Guideline. Q1A (R2)-stability testing of new drug substances and products. ICH, 2003. Available at: http://www.ich.org/fileadmin/Public_Web_ Site/ICH_Products/Guidelines/Quality/Q1A_R2/Step4/ Q1A_R2_Guideline.pdf. Accessed on: Mar. 2013

JAN, S.U.; KHAN, G.M.; KHAN, K.A.; REHMAN, A.; KHAN, H. In vitro release pattern of Ketoprofen using ethyl cellulose ether derivatives. J. App. Pharm, v.1, n.3, p.149-158, 2011.

KOLTER, K. Compression behaviour of kollidon SR. Proc. 4th World meeting on Pharm. Biol. Pharm. Pharm. Technol, 2002. p.119-120.

KORSMEYER, R.W.; GURNY, R.; DOELKER, E.; BURI, P.; PEPPAS, N.A. Mechanisms of solute release from porous hydrophilic polymers. Int J. Pharm, v.15, n.1, p.25-35, 1983.

KULKARNI, G.S.; BABU, P.S. Design and evaluation of tizanidine buccal mucoadhesive patches. J. Appl. Pharm. Sci., v.2, n.4, p.74-81, 2012.

LIYANA-PATHIRANA, C.; SHAHIDI, F. Optimization of extraction of phenolic compounds from wheat using response surface methodology. Food Chem., v.93, n.1, p.47-56, 2005.

MEYTHALER, J.M.; GUIN-RENFROE, S.; JOHNSON, A.; BRUNNER, R.M. Prospective assessment of tizanidine for spasticity due to acquired brain injury. Arch. Phys. Med. Rehabil.,v.82, n.9, p.1155-1163, 2001.

MOFFAT, A.C.; OSSELTON, D.M.; WIDDOP, B. Clarke's analysis of drugs and poisons: in pharmaceuticals, body fluids, and postmortem material. $4^{\text {th }}$ ed. Pharmaceutical Press, 2011. p.2161-2162.
NERURKAR, J.; JUN, H.; PRICE, J.; PARK, M. Controlledrelease matrix tablets of ibuprofen using cellulose ethers and carrageenans: effect of formulation factors on dissolution rates. Eur. J. Pharm. Biopharm., v.61, n.1, p.56-68, 2005.

PEPPAS, N. Analysis of fickian and non-fickian drug release from polymers. Pharm. Acta Helv., v.60, n.4, p.110, 1985.

POLLI, J.E.; REKHI, G.S.; AUGSBURGER, L.L.; SHAH, V.P. Methods to compare dissolution profiles and a rationale for wide dissolution specifications for metoprolol tartrate tablets. J. Pharm. Sci., v.86, n.6, p.690-700, 1997.

QUADIR, M.A.; CHANDA, E.; HAIDER, S.S.; REZA, M.S.; DATTA, B.K. Evaluation of ethylcellulose ss matrices for controled release drug delivery. Pak. J. Pharm. Sci., v.18, n.2, p.29-34, 2005.

REZA, M.S.; QUADIR, M.A.; HAIDER, S.S. Comparative evaluation of plastic, hydrophobic and hydrophilic polymers as matrices for controlled-release drug delivery. J. Pharm. Pharm. Sci., v.6, n.2, p.282-91, 2003.

RONI, M.A.; KIBRIA, G.; JALIL, R.U. In vitro studies of controlled release alfuzosin matrix tablets prepared with ethylcellulose and hydroxypropyl methylcellulose. Iran J. Pharm. Sci., v.5, n.2, p.59-68, 2009.

SAHOO, J.; MURTHY, P.; BISWAL, S.; SAHOO, S.; MAHAPATRA, A. Comparative study of propranolol hydrochloride release from matrix tablets with Kollidon ${ }^{\circledR} \mathrm{SR}$ or hydroxy propyl methyl cellulose. AAPS PharmSciTech, v.9, n.2, p.577-582, 2008.

SALÚSTIO, P.; CABRAL-MARQUES, H.; COSTA, P.; PINTO, J. Comparison of ibuprofen release from minitablets and capsules containing ibuprofen: $<\mathrm{i}>\beta</ \mathrm{i}>$-Cyclodextrin complex. Eur. J. Pharm. Biopharm., v.78, n.1, p.58-66, 2011.

SANKALIA, J.M.; SANKALIA, M.G.; MASHRU, R.C. Drug release and swelling kinetics of directly compressed glipizide sustained-release matrices: establishment of level A IVIVC. J. Control. Release, v.129, n.1, p.49-58, 2008.

SAPER, J.R.; LAKE, A.E.; CANTRELL, D.T.; WINNER, P.K.; WHITE, J.R. Chronic daily headache prophylaxis with tizanidine: a double-blind, placebo-controlled, multicenter outcome study. Headache, v.42, n.6, p.470-482, 2002. 
SAVAȘER, A.; ÖZKAN, Y.; IȘMER, A. Preparation and in vitro evaluation of sustained release tablet formulations of diclofenac sodium. Farmaco, v.60, n.2, p.171-177, 2005.

SHANKER, G.; KUMAR, C.K.; GONUGUNTA, C.S.R.; KUMAR, B.V.; VEERAREDDY, P.R. Formulation and evaluation of bioadhesive buccal drug delivery of tizanidine hydrochloride tablets. AAPS Pharmscitech, v.10, n.2, p.530$539,2009$.

SHAO, Z.J.; FAROOQI, M.I.; DIAZ, S.; KRISHNA, A.K.; MUHAMMAD, N.A. Effects of formulation variables and post-compression curing on drug release from a new sustained-release matrix material: polyvinylacetatepovidone. Pharm. Dev. Technol., v.6, n.2, p.247-254, 2001.

SHOAIB, M.H.; SIDDIQI, S.A.S.; YOUSUF, R.I.; ZAHEER, K.; HANIF, M.; REHANA, S.; JABEEN, S. Development and evaluation of hydrophilic colloid matrix of famotidine tablets. AAPS Pharmscitech, v.11, n.2, p.708-718, 2010.

SIDDIQUI, A.; NAZZAL, S. Measurement of surface color as an expedient QC method for the detection of deviations in tablet hardness. Int. J. Pharm., v.341, n.1-2, p.173-180, 2007.

SIEPMANN, J.; STREUBEL, A.; PEPPAS, N. Understanding and predicting drug delivery from hydrophilic matrix tablets using the "sequential layer" model. Pharm. Res., v.19, n.3, p.306-314, 2002.

STRÜBING, S.; METZ, H.; MÄDER, K. Characterization of poly (vinyl acetate) based floating matrix tablets. J. Control. Release,v.126, n.2, p.149-155, 2008.

SWEETMAN, S.C. Martindale: the complete drug reference. 36th ed. London: Pharmaceutical Press, 2009. 1899 p.

THE UNITED STATES PHARMACOPEIAL CONVENTION. USP35-NF30. USA: The United States Pharmacopeial Convention, 2012. Accessed on: Dec. 2012.
VICENTE, G.; COTERON, A.; MARTINEZ, M.; ARACIL, J. Application of the factorial design of experiments and response surface methodology to optimize biodiesel production. Ind. Crops Prod., v.8, n.1, p.29-35, 1998.

WAGSTAFF, A.; BRYSON, H. Tizanidine: a review of its pharmacology clinical efficacy and tolerability in the management of spasticity associated with cerebral and spinal disorders. Drugs, v.53, n.3, p.435-452, 1997.

WILSON, C.G.; CROWLEY, P.J. Controlled release in oral drug delivery. Springer: New York, 2011. p.1-26.

XIONG, Y.; GUO, D.; WANG, L.; ZHENG, X.; ZHANG, Y.; CHEN, J. Development of nobiliside a loaded liposomal formulation using response surface methodology. Int. $J$. Pharm., v.371, n.1, p.197-203, 2009.

ZHANG, X.; LIU, J.; QIAO, H.; LIU, H.; NI, J.; ZHANG, W.; SHI, Y. Formulation optimization of dihydroartemisinin nanostructured lipid carrier using response surface methodology. Powder Technol., v.197, n.1, p.120-128, 2010a.

ZHANG, Y.; HUO, M.; ZHOU, J.; ZOU, A.; LI, W.; YAO, C.; XIE, S. DDSolver: an add-in program for modeling and comparison of drug dissolution profiles. AAPSJ., v.12, n.3, p.263-271, 2010b.

ZHANG, Z.S.; LI, D.; WANG, L.J.; OZKAN, N.; CHEN, X.D.; MAO, Z.H.; YANG, H.Z. Optimization of ethanol-water extraction of lignans from flaxseed. Sep. Purif. Technol., v.57, n.1, p.17-24, 2007.

Received for publication on $22^{\text {nd }}$ July 2013 Accepted for publication on $10^{\text {th }}$ March 2014 